\title{
La trata de personas y la explotación de menores de edad
}

No existe coincidencia entre los tipos penales contenidos en los artículos 188A y 188B del Código Penal y los previstos en el artículo 93 de la Ley 1453 de 2011; la expresión "mendigue con menores de edad", contenida en este último dispositivo legal, es constitucional de forma condicionada siempre y cuando se entienda que ella "tipifica exclusivamente la utilización de menores de edad para el ejercicio de la mendicidad y no el ejercicio autónomo de la misma en compañía de estos", este último comportamiento, dice la jurisprudencia de manera reiterada, no pude ser castigado en un Estado de Derecho.

Fernando Velásquez Velásquez.

\section{Sentencia C-464/14}

Referencia: expediente No. D-9972

Demanda de inconstitucionalidad contra el artículo 93 de la Ley 1453 de 2011 "por medio de la cual se reforma el Código Penal, el Código de Procedimiento Penal, el Código de Infancia y Adolescencia, las reglas sobre extinción de dominio y se dictan otras disposiciones en materia de seguridad".

Demandante: María Eugenia Gómez Chiquiza

Magistrado Ponente: ALBERTO ROJAS RÍOS

Bogotá D. C., nueve (9) de julio de dos mil catorce (2014)

La Sala Plena de la Corte Constitucional, en ejercicio de sus atribuciones constitucionales y de los requisitos y trámites establecidos en el Decreto 2067 de 1991, ha proferido la siguiente

\section{SENTENCIA}

\section{ANTECEDENTES}

En ejercicio de la acción pública consagrada en el artículo 241 de la Constitución, la ciudadana María Eugenia Gómez Chiquiza solicita a la Corte 
que declare la inexequibilidad de la totalidad del artículo 93 de la Ley 1453 de 2011 "por medio de la cual se reforma el Código Penal, el Código de Procedimiento Penal, el Código de Infancia y Adolescencia, las reglas sobre extinción de dominio y se dictan otras disposiciones en materia de seguridad". Cumplidos los trámites previstos en el artículo 242 de la Constitución y en el Decreto Ley 2067 de 1991, procede la Corte a resolver sobre la demanda de la referencia.

\section{NORMA DEMANDADA}

A continuación se transcribe la norma demandada, publicada en el Diario Oficial No. 48.110 de 24 de junio de 2011:

“LEY 1453 DE 2011 (junio 24). Diario Oficial No. 48.110 de 24 de junio de 2011. CONGRESO DE LA REPÚBLICA. Por medio de la cual se reforma el Código Penal, el Código de Procedimiento Penal, el Código de Infancia y Adolescencia, las reglas sobre extinción de dominio y se dictan otras disposiciones en materia de seguridad.

\section{EL CONGRESO DE COLOMBIA DECRETA: (...) ARTÍCULO} 93. EXPLOTACIÓN DE MENORES DE EDAD. El que utilice, instrumentalice, comercialice o mendigue con menores de edad directamente o a través de terceros incurrirá en prisión de 3 a 7 años de prisión y el menor será conducido al Instituto Colombiano de Bienestar Familiar para aplicar las medidas de restablecimientos de derechos correspondientes. /La pena se aumentará a la mitad cuando el actor sea un pariente hasta el cuarto grado de consanguinidad, segundo de afinidad o primero civil".

\section{LA DEMANDA}

La ciudadana María Eugenia Gómez Chiquiza presentó acción de inconstitucionalidad contra el artículo 93 de la Ley 1453 de 2011 "por medio de la cual se reforma el Código Penal, el Código de Procedimiento Penal, el Código de Infancia y Adolescencia, las reglas sobre extinción de dominio y se dictan otras disposiciones en materia de seguridad", por presunta inconstitucionalidad en su contenido material.

A juicio de la actora la disposición legal demandada vulnera los artículos 9, 13, 17, 28, 29, 44, 93 y 94 de la Constitución Política, el artículo 25 del Convenio No. 29 relativo al trabajo forzoso u obligatorio, el artículo $2^{\circ}$ del Convenio No. 105 sobre la abolición del trabajo forzoso, el artículo $2^{\circ}$, numeral $2^{\circ}$ y el artículo $8^{\circ}$ numeral $1^{\circ}$ del Pacto Internacional de Derechos Civiles y Políticos, los artículos $1^{\circ}, 2^{\circ}$ y 19 de la Convención Americana de Derechos Humanos, los artículos $2^{\circ}$, numeral $2^{\circ}$, artículo $3^{\circ}$, numeral $1^{\circ}$ y $2^{\circ}$, artículo $4^{\circ}$, artículo 19 numeral $1^{\circ}$ y $2^{\circ}$, artículo 32 , artículo 34 , artículo 35 , artículo 36 y artículo 41 de la Convención sobre Derechos del Niño, artículos $1^{\circ}$ y $7^{\circ}$ numeral $1^{\circ}$ del Convenio No. 182 Sobre Prohibición de las Peores Formas de Trabajo Infantil y la Acción Inmediata Para su Eliminación y los artículos $3^{\circ}$ literal C y $5^{\circ}$ del Protocolo para Prevenir, Reprimir y Sancionar la Trata de Personas especialmente de Mujeres y Niños. 
La demanda fue inicialmente admitida mediante auto del 26 de noviembre de 2013 en lo correspondiente a los cargos por presunta vulneración del principio de igualdad (artículo 13 de la Constitución) y presunta vulneración del derecho al debido proceso (artículo 29 de la Constitución). No obstante, en el mismo proveído se decidió inadmitir la demanda respecto a los cargos por presunta vulneración de los artículos 9, 17, 28, 44, 93 y 94 de la Constitución.

La actora presentó de manera extemporánea correcciones a la demanda, el día 04 de diciembre de 2013, por los cargos inadmitidos, por lo cual se procedió mediante auto fechado el 13 de diciembre de 2013 al rechazo de los mismos, sin objeto de controversia ante la Sala Plena de esta Corporación por la falta de interposición del recurso de súplica. En consecuencia, la presente acción de inconstitucionalidad se circunscribe a cargos por presunta vulneración al principio de igualdad y al debido proceso.

Los fundamentos para solicitar la inconstitucionalidad son:

1.- La conducta prescrita en el artículo 93 de la Ley 1453 de 2011 relativa a la explotación de menores genera una confusión típica cuando se observa de conformidad con el artículo 188-A del Código Penal (Ley 599 de 2000) que consagra el tipo penal de trata de personas.

En palabras de la demandante "la conducta típica descrita en el artículo 93 de la Ley 1453 de 2011 y que establece la explotación de menores de edad (en diferentes modalidades, por cuanto entraña su utilización, instrumentalización, comercialización o el ejercicio de la mendicidad), coincide con los aspectos fácticos, jurídicos y aún probatorios de la conducta punible que concibe el delito de trata de personas establecido en el artículo 188 A del Nuevo Código Penal, al configurarse este por la explotación de las personas (incluidos los menores de edad cuando en el artículo 188 B se prevén las circunstancias de agravación) en sus diferentes modalidades, creándose una confusión típica, toda vez que los dos tipos penales entrañan la misma conducta y buscan proteger el bien tutelado que es "la libertad individual y autonomía personal" -folios 8 y 9-.

2.- En ese sentido, para la demandante, una vez analizados los verbos rectores de ambos tipos penales, el tipo penal demandado se encuentra subsumido totalmente por el tipo penal anterior contenido en el Código Penal colombiano. Este supuesto de hecho conlleva a una presunta vulneración del principio de igualdad (art. 13. C.P.) por cuanto el artículo demandado, referente a menores de edad, establece una protección inferior con una pena de 3 a 7 años para quien explote a los menores de edad, mientras el artículo 188-A en comparación, consagra una pena de 13 a 23 años frente al adulto que sea víctima de explotación por cualquiera de sus modalidades.

Según la actora, la nueva regulación es irrazonable y desproporcionada ya que el menor de edad por su condición de especial protección y debilidad manifiesta debería contar con una mayor protección que el adulto. En su 
concepto, resulta reprochable constitucionalmente que "quien en condición de superioridad o confianza se aprovecha del sufrimiento de pesar que produce un niño mendigando, y por tanto, resulta necesario que tal conducta reprochable sea sancionada penalmente atendiendo su gravedad, de tal forma que se castigue con más severidad al que mendiga con un menor de edad, que al que mendiga utilizando un adulto" -folio 13-. Más adelante, indica otra presunta desigualdad ya que el nuevo tipo penal puede resultar excarcelable mientras el contenido en el artículo 188A del Código penal no.

3.- Partiendo del mismo presupuesto de la demandante (sic), es decir, de la subsunción de dos tipos penales, la demandante estima que el legislador desconoció el principio de non bis in ídem, contenido en el derecho al debido proceso, que supone en su criterio: "el de prohibición o múltiple incriminación, prohibición de doble o múltiple valoración, el denominado principio del non bis in ídem material, cosa juzgada, prohibición de doble o múltiple punición y finalmente, el non bis in idem material" -folio 9-.

4. Para la actora esta dualidad normativa genera una tipificación vaga por parte del legislador que atenta contra el principio de legalidad, ya que no existe precisión y certeza en la ley penal, lo cual se refleja en la seguridad del ciudadano quien necesita conocer de antemano "qué conductas son catalogadas por los jueces como delitos y qué sanciones jurídicas ocasionará la realización de tales conductas"-folio 15-.

5.- De manera particular, la actora indica que la expresión "o mendigue con menores de edad" contenida en el artículo demandado vulnera el debido proceso al pretender tipificar la mendicidad con menores de edad, sin tener en consideración la realidad del país, en la que muchas familias por situaciones de extrema pobreza, desplazamiento o imposibilidad de encontrar empleo formal o informal, obtienen de esta forma ingresos para satisfacer necesidades básicas y optan por la mendicidad como único medio de subsistencia, sin la menor intención de explotar económicamente a sus hijos, a través de su acompañamiento. Por ello, la disposición demandada permite concluir que "un padre o madre en las condiciones antes dichas que sea sorprendido ejerciendo la mendicidad propia pero en compañia de sus hijos menores de edad, puede ser judicializado por el delito de mendicidad ajena, constituyéndose esto en una forma de criminalizar la pobreza" -folio 15. Al respecto, cita la sentencia C-040 de 2006 en la cual la Corte precisó que es legítimo el ejercicio de la mendicidad propia, pues la misma no afecta derechos de terceros y, por el contrario, puede constituir para la persona un elemento vital de realización personal.

\section{INTERVENCIONES}

\section{Ministerio del Interior}

El representante del Ministerio del Interior, Andrés Gómez Roldán solicita declarar exequible el artículo 93 de la Ley 1453 de 2011 por cuanto 
la normatividad penal expone tipos punitivos diferentes, los cuales si bien impactan en cierta medida la conducta antijurídica de trata de personas, no se pueden estimar vulneratorios de la Constitución; ya que por el contrario, al tipificar conductas penales diferentes podrían construir para el ejecutor un marco integrador de la normatividad en la materia. Dentro de esas disposiciones cita: reclutamiento ilícito (art. 162); tráfico de menores (art. 188); trata de personas (art. 188A); tráfico de niñas, niños y adolescentes (artículo 188C); uso de menores de edad (art. 188D); prostitución forzada o esclavitud sexual (art. 141); turismo sexual (art. 129); demanda de explotación sexual y comercial de persona menor de 18 años (art. 217A); pornografía con personas menores de 18 años (art. 218); inducción a la prostitución (art. 213); proxenetismo con menor de edad (art. 213A) y; constreñimiento a la prostitución (art. 214).

Indica que los verbos rectores que configuran la conducta punible de explotación de menores de edad, "utilizar, instrumentalizar, comercializar o mendigar" con menores de edad directamente, difiere de lo previsto en el artículo 188 A del Código Penal, el cual desarrolla las conductas atinentes a "captar, trasladar, acoger o recibir" a una persona, dentro del territorio nacional o hacia el exterior, con fines de explotación.

Por consiguiente, para esta entidad la disposición demandada se enmarca en la libertad de configuración legislativa, y "se dirige a garantizar el principio de exclusiva protección de bienes jurídicos como valores esenciales de la sociedad, configurando una conducta punible diferente a la prevista en el artículo $188 \mathrm{~A}$ del Código Penal y demás normatividad que existe en la materia" -folio 76-.

Finalmente, respecto de la particular expresión acusada "o se mendigue con menores de edad" el interviniente señala que la demandante además de ignorar el principio de libre configuración de la Ley, expone argumentos impertinentes e insuficientes, pues se trata de meras consideraciones subjetivas con el propósito de deslegitimar la sanción penal dirigida a penalizar la explotación de menores con fines de mendicidad.

\section{Defensoría del Pueblo}

El Defensor Delegado para Asuntos Constitucionales y Legales de la Defensoría del Pueblo, Luis Manuel Castro Novia, solicita la exequibilidad del cargo por presunta vulneración del derecho a la igualdad y declarar la exequibilidad condicionada de la expresión "o mendigue con menores de edad", contenida en el artículo 93 de la Ley 1453 de 2011, "bajo el entendido que la conducta reprochable es el ejercicio de la mendicidad utilizando o valiéndose de menores de edad, mas no el ejercicio autónomo de la misma en compañía de estos" -folio 93-.

Para la Defensoría del Pueblo el aparte acusado puede representar una forma de criminalizar la pobreza ya que incorpora elementos que constituyen un riesgo frente a la imputación de delitos a personas que por 
su condición de extrema pobreza y miseria, se ven obligados a realizar acciones de mendicidad con el fin de cubrir en algún grado sus necesidades, en algunos casos, en compañía o en presencia de niños, niñas o adolescentes, acción que no implica necesariamente un acto de explotación hacia el niño o la niña que acompaña al adulto a realizar esta actividad.

Asimismo, según el interviniente el tipo penal demandado "no ofrece elementos para identificar si estos actos de mendicidad, en presencia de niños o niñas, son derivados de situaciones de extrema necesidad o urgencia manifiesta o efectivamente corresponden a actos de explotación infantil, que a juicio de la entidad, debe constituir el núcleo de este tipo penal" -folio 91-.

Respecto a la supuesta vulneración del derecho a la igualdad, estima que no le asiste razón a la demandante por tres razones. En primer lugar, los tipos penales no son susceptibles de comparación teniendo en cuenta sus características y en atención a las finalidades que persiguen, "si bien estos tipos pretenden castigar "la instrumentalización o cosificación de las personas", lo cierto es que sus elementos característicos son diferentes, pues aunque protegen el mismo bien jurídico, contienen distintos verbos rectores y distinto sujeto pasivo. (...) En esa medida, puede afirmarse que el delito de trata de personas consagrado en el artículo 188 A del Código Penal castiga la "explotación de personas" de una manera más amplia y detallada, ampliando las posibilidades de realizar esta conducta, mientras que el delito de explotación de menores, contenido en el artículo 93 de la Ley 1453 de 2011, circunscribe la explotación a un ámbito específico, cual es, su realización en menores de edad. En consecuencia, al ser diferentes los tipos penales sujetos a comparación no es posible aducir la vulneración del derecho a la igualdad" -folio 89-.

En segundo lugar, la tipificación de la explotación de menores, lejos de desconocer el mandato contenido en el artículo 13 de la Carta Política, constituye un instrumento de protección a favor de los menores de edad y no debe verse bajo ninguna circunstancia como una disposición que minimice, relativice o desconozca las afectaciones de las que son víctimas, independientemente de que el tipo penal contenga una pena inferior a la contemplada en el delito de trata de personas.

Finalmente, considera esta entidad que la demanda carece de certeza ya que la conducta descrita en el delito de trata de personas no contempla diferenciación alguna de edad $\mathrm{y}$, al usar la palabra "persona" se tiene claramente que los menores de edad pueden ser igualmente víctimas de esta conducta.

\section{Ministerio de Justicia y del Derecho}

La apoderada, Ana Beatriz Castelblanco Burgos interviene en la acción de inconstitucionalidad de la referencia con el fin de solicitar un fallo inhibitorio por cuanto la demanda carece de certeza al estar estructurada subjetivamente sobre el contenido de una norma acusada que no penaliza la mendicidad propia ni la comercialización de los menores. 
Como antecedente legislativo de la disposición demandada la interviniente manifiesta que la disposición demandada surgió en tercer debate en la Comisión Primera de Cámara, como consecuencia de una proposición presentada por el Representante Juan Carlos Salazar Uribe "sin que viniera incluida en la Ponencia y sin que hubiera sido objeto de discusión, propuesta o debate en las etapas previas en el Senado" -folio 96-.

Sin embargo concluye, así no exista justificación, sentido, alcance y finalidad por parte del legislador que el contexto general del artículo 93 demandado no persigue penalizar la explotación de menores en el marco de la trata de personas, sino en el sentido de no utilizar menores en el marco de la misericordia o compasión que facilita la obtención de limosna.

Finalmente, aduce que la norma acusada no se está diversificando el delito de trata de personas para concentrarlo para el caso de explotación de adultos y excluirlo para el caso de explotación de menores, pues la explotación que se tipifique en el marco de cualquiera de los verbos rectores consagrados en el artículo 188-A del Código Penal aplica tanto para adultos como para menores.

\section{Instituto Colombiano de Bienestar Familiar}

La Jefe de Oficina Asesora Jurídica del Instituto Colombiano de Bienestar Familiar -en adelante ICBF-, intervine para solicitar la declaratoria de inexequibilidad del artículo 93 de la Ley 1453 de 2011.

Señala que este caso trata de dos normas con el mismo fin, que buscan proteger el mismo bien jurídico, la libertad individual y la autonomía personal. Del mismo modo precisa que la cuestión constitucional versa sobre niños quienes son considerados sujetos de especial protección constitucional, con derechos e intereses superiores y prevalentes

Aduce que "el legislador sobrepasó los límites constitucionales fijados frente a la potestad de configuración legislativa, por cuanto al momento de crear la norma jurídica objeto de esta demanda, no tuvo en cuenta que ya existía en otro cuerpo normativo (Código Penal), una tipificación que incluye la explotación de menores de 18 años (artículo 188A), la cual resulta ser más garantista de los derechos de los niños y prevé una sanción acorde no sólo con la gravedad que representa para la niñez y la adolescencia este delito, sino que responde a la exigencia que se impone al Estado frente a los tratados y convenios internacionales.

Ahora bien, la sanción del Estado como garante de los derechos de sus ciudadanos, debe ser proporcional el daño causado, por lo que es imperativo señalar que ningún estudio científico ni empírico, ha demostrado que las secuelas de las víctimas de trata, estén disminuyendo y por lo mismo una disminución de la pena carece de fundamento social, conceptual y ético" - reverso folio 110-.

Además, cita la sentencia C-121 de 2012 para concluir que la sanción establecida en el artículo 93 de la Ley 1453 de 2011 vulnera los principios 
de razonabilidad, proporcionalidad y resulta poco idónea para proteger el bien jurídico pretendido.

\section{Fundación Telefónica Colombia}

El Director (E) de la Fundación Telefónica Colombia, Javier Uribe Blanco, interviene para solicitar la inexequibilidad de la norma demandada. En su criterio esta disposición desconoce la prevalencia que ha sido dada a los derechos de los niños por vía constitucional de acuerdo a los tratados suscritos por Colombia ya que establece una discriminación sin justificación. Lo anterior, contradice los estudios que indican que la sola acción del trabajo infantil ya es violatoria de derechos individuales y colectivos y que merece el mayor repudio punitivo para quien tipifique esta conducta.

En palabras de la Fundación "la conducta descrita en el artículo 93 de la Ley 1453 de 2011 y que establece la explotación de menores de edad coincide con la conducta punible descrita por el delito de trata de personas establecido en el artículo 188 A del Código Penal, al configurarse este por la explotación de las personas. Este delito incluye a los menores de edad cuando en el artículo $188 \mathrm{~B}$ se prevén las circunstancias de agravación en sus diferentes modalidades, creándose una confusión en el tipo penal para la tipificación de la conducta punitiva. Esta situación, es contradictoria y genera confusión para el juez de conocimiento del caso, lo cual no sólo debilita el sistema penal como un todo, sino que genera la inseguridad jurídica para los niños, niñas y adolescentes víctimas del delito afectando su preponderancia en la escala de derechos" -folios 115 y 116-.

\section{Universidad Nacional de Colombia}

Mediante oficio No. VDA-35-2014, el Vicedecano Académico, Gregorio Mesa Cuadros, solicita que la Corte declare la exequibilidad del artículo 93 de la Ley 1453 de 2011, no obstante, suplica que se declare inexequible la expresión "o mendigue con menores de edad" al ser contraria a la Constitución.

En primer lugar, parte su exposición en denotar una diferenciación en cuanto a los verbos rectores de los tipos penales, para concluir que la trata de personas prevé un ingrediente subjetivo especial "con fines de explotación", "de manera que para la configuración del delito es suficiente que se realice, alternativamente, uno de los verbos rectores con la finalidad de explotar a la víctima, aunque dicha explotación no se realice. En otras palabras, para la configuración de la conducta punible no se requiere la explotación propiamente en cualquiera de sus modalidades, si no que la acción se realice con ese fin" -folio 119-.

Por lo cual, la norma acusada no constituye una vulneración del derecho a la igualdad en sentido material, sino que protege de manera distinta a las víctimas de los delitos analizados, al establecer además del delito de trata de personas, un delito especial para la protección de los menores.

Frente a la violación del debido proceso, el interviniente funda la inexequibilidad del aparte demandado "o mendigue con menores de edad", 
en que su contenido es genérico, amplio y puede representar una forma de criminalizar la mendicidad al incorporar una conducta que en estricto sentido no se corresponde con el objeto de protección, sino que "implica una norma selectiva que apunta a la criminalización de la población menos favorecida, aquella que por condiciones materiales o precarias se ve compelida a la mendicidad"- folio 121-.

Indica que la realidad social del país muestra cómo las personas que se encuentran en debilidad manifiesta, en condiciones de vulnerabilidad o en riesgo permanente por la pobreza, "pueden verse obligados a ejercer la mendicidad, solos, en grupos familiares, en grupos de desplazados o en presencia de menores, entre otros, sin que con ello estén actuando con la intención final de explotar económicamente a éstos últimos. En ese sentido, la descripción típica presume el actuar doloso de quien ejerce la mendicidad con menores, como una mera conducta, cuando ello no siempre es así. Al estar proscrita la responsabilidad objetiva, el tipo penal desborda sin una razón válida los límites al poder punitivo impuestos desde la Constitución Política de Colombia" -folio 121-.

Por lo anterior, al considerar que se desbordaron los límites impuestos a la libertad de configuración en materia político criminal y que se crea un riesgo objetivo al tipificar una conducta realizada por población vulnerable o en estado de pobreza solicita la declaratoria de inconstitucionalidad.

\section{Departamento Administrativo para la Prosperidad Social}

Lucy Edrey Acevedo Meneses, interviene en calidad de Jefe de la Oficina Asesora Jurídica del Departamento Administrativo para la Prosperidad Social, con el fin de solicitar la exequibilidad de la norma acusada.

Indicó que para la Corte Constitucional el legislador es quien debe regular la política criminal del Estado de manera amplia, lo cual incluye la facultad de crear, modificar o suprimir figuras delictivas, introducir clasificaciones entre ellas, modalidades punitivas, graduar las penas aplicables, fijar la clase y magnitud de las penas, entre otras.

Ahora bien, respecto al delito de trata de personas señala que este tipo penal es pluriofensivo y tiene tres elementos constitutivos que pueden sintetizarse así: "(i) la movilización de un individuo -mujer, hombre, niño y niñafuera de su entorno social; (ii) los medios, o los métodos por los cuales una persona es limitada o privada de la libertad - a través del uso de la fuerza, la amenaza, la servidumbre por deudas, el fraude y la coacción, entre otros-y; (iii) los fines de explotación" -folio 127-.

Sin embargo, para la interviniente así el tipo penal tenga como fin la explotación, el legislador tenía amplio margen para considerar que la conducta abarca de manera directa las situaciones que afecten directamente a los menores de edad. Es más, por el carácter de protección reforzada de la que son objeto era más beneficioso establecer la conducta cuando se cometa específicamente sobre menores de edad. 


\section{CONCEPTO DEL PROCURADOR GENERAL DE LA NACIÓN}

En ejercicio de las competencias previstas en los artículos 242.2 y 278 del texto constitucional, el Procurador General de la Nación, el 25 de febrero de 2014, presentó concepto número 5734, en el cual solicitó a la Corte declarar la exequibilidad de la norma acusada por cuanto el tipo penal de trata de personas y el de explotación de menores tutelan bienes jurídicos distintos, castigan distintas conductas, y en suma, poseen espectros sancionatorios diferentes. Además, para el Ministerio Público la norma atacada no sanciona objetivamente la mendicidad del adulto.

En primer lugar, el Procurador General de la Nación indicó en su concepto que el tipo penal de trata de personas es un delito complejo no solo porque posee cuatro verbos rectores diferentes (captar, trasladar, acoger y recibir) sino porque contiene un ingrediente subjetivo concreto de realizar cualquiera de los verbos rectores con la intención de explotar. También contiene un ingrediente objetivo como es que los verbos rectores deben configurarse dentro del territorio nacional o hacia el exterior. Por su parte, en el tipo penal de explotación de menores de edad se establecen tres verbos rectores (instrumentalizar, comercializar o mendigar) distintos, que si bien pueden contener alguna relación con los ingredientes subjetivos del delito de trata, no por ello reprimen los mismos hechos, ya que en este tipo penal la conducta sancionada sí posee como resultado directo la explotación del menor de edad.

En segundo lugar, para la Vista Fiscal el delito de trata de personas catalogado como de esclavitud moderna, no tiene la finalidad de castigar el hecho de la explotación en sí misma, sino un tipo particular de ésta, en el cual "el ser humano resulta cosificado al punto de llegarse a establecerse relaciones de dominio en las que se generan relaciones de señorí y el ser humano es tratado como un objeto que se capta, traslada, acoge o recibe con fines de explotación" -folio $144-$.

En tercer lugar, precisa el concepto que "en la trata de personas no se castiga el resultado de explotación, sino la intención de explotar a través de la captación, traslado, acogida o recibimiento cosificado de seres humanos. En tal sentido, el delito referido no tiene por objeto la sanción de la explotación efectiva, con lo cual el delito se comete sin necesidad que la explotación se realice, pues lo que se debe configurar es el acogimiento, traslado, captación, recibimiento con dicho fin. En otras palabras, como el delito de trata de personas castiga la captación, traslado, acogida o recibimiento con fines de explotación, en nada se opone a que se presente en concurso con delitos que sancionen efectivamente la explotación ajena como verbo rector" -folio 145-.

De otra parte, la intervención concluye en este punto con que la dogmática penal ofrece el fenómeno de la consunción que opera cuando el juicio de desvalor de una conducta punible se encuentra comprendida en 
el juicio de desvalor de otra, que es aplicable en razón de su mayor riqueza descriptiva, contenido, etc., en otras palabras, el injusto más complejo absorbe los otros que en aquél se hayan consumado. Por lo anterior, no existiría confusión o verdadera coincidencia entre el tipo penal de trata de personas y el de explotación de menores de edad, por cuanto uno está llamado a sancionar la intención de explotar, desarrollada a través de acciones distintas a la explotación en sí misma, y el otro está destinado a reprimir directamente la conducta de explotar a otro ser humano.

Ahora bien, para el Ministerio Público el cargo por inconstitucionalidad de la expresión "o mendigue con menores de edad", contenido en el artículo demandado deviene de una lectura parcial de la norma acusada, dando una interpretación errónea a la expresión con menores de edad. Si bien esta entidad reconoce que la expresión tiene una doble interpretación, ya que puede entenderse que se castiga el hecho de mendigar estando acompañado por un menor de edad, la frase debe entenderse correctamente de forma armónica con el resto del delito, es decir, de conformidad con su título explotación de menores de edad, concluyéndose que la conducta criminalizada es la de mendigar utilizando o instrumentalizando a un menor de edad para el despliegue de la actividad.

\section{CONSIDERACIONES Y FUNDAMENTOS}

\section{La competencia y el objeto del control}

La Corte Constitucional es competente, de conformidad con lo dispuesto en el numeral 4 del artículo 241 de la Constitución, para pronunciarse sobre la demanda de inconstitucionalidad presentada contra el artículo 93 de la Ley 1453 de 2011 "por medio de la cual se reforma el Código Penal, el Código de Procedimiento Penal, el Código de Infancia y Adolescencia, las reglas sobre extinción de dominio y se dictan otras disposiciones en materia de seguridad".

\section{Planteamiento del caso y problema jurídico}

Mediante acción de inconstitucionalidad la ciudadana María Eugenia Gómez Chiquiza solicita a la Corte Constitucional declarar la inexequibilidad del artículo 93 de la Ley 1453 de 2011, por cuanto la conducta descrita, relativa a la explotación de menores genera una confusión típica cuando se confronta con el delito de trata de personas, contenido en el artículo 188-A del Código Penal. En criterio de la demandante, al analizar el ingrediente subjetivo del tipo penal contenido en la trata de personas, se puede entender subsumido el tipo penal de explotación de menores. En ese entendido, el tipo penal de explotación de menores transgrede el principio de igualdad al introducir al ordenamiento jurídico una pena menor para sancionar la explotación de menores, en comparación con la prevista para castigar el mismo acto en los adultos, lo cual vulnera la especial protección constitucional que merecen los niños. 
Por otra parte, la actora también estima que el artículo demandado vulnera las garantías del debido proceso en lo relativo al principio de non bis in ídem, por cuanto al encontrarse la norma demandada subsumida en otra anterior, coexisten dos sanciones penales distintas para una misma conducta. Finalmente, según la demanda, la expresión "o mendigue con menores de edad" contenida en el artículo 93 demandado, pretende tipificar la mendicidad con menores de edad, sin tener en consideración la realidad del país. Por ello, para la demandante la disposición demandada permite concluir que "un padre o madre en las condiciones antes dichas que sea sorprendido ejerciendo la mendicidad propia pero en compañia de sus hijos menores de edad, puede ser judicializado por el delito de mendicidad ajena, constituyéndose esto en una forma de criminalizar la pobreza" -folio 15-.

Frente a tales cuestionamientos, el Ministerio del Interior, el Departamento Administrativo para la Prosperidad Social, la Defensoría del Pueblo, la Universidad Nacional de Colombia y el Procurador General de la Nación, intervinieron con el fin de solicitar la declaratoria de exequibilidad de la disposición demandada por cuanto los dos tipos penales confrontados son claramente diferenciables, lo cual conduce a desestimar los cargos por violación del principio de igualdad y, por ende, del debido proceso.

No obstante, el Instituto Colombiano de Bienestar Familiar y la Fundación Telefónica de Colombia acompañan los argumentos de la demandante al considerar que el control constitucional debe producir una inexequibilidad de la norma acusada, toda vez que según los verbos rectores, la norma demandada puede subsumirse en el tipo penal de trata de personas, ambas protegen un mismo bien jurídico y, por tanto, ocasionan una graduación punitiva inferior y desproporcionada respecto de los derechos de los niños.

Con relación a la expresión "o mendigue con menores de edad" la Universidad Nacional de Colombia estima que debe declararse la inexequibilidad de la misma, en similar sentido, la Defensoría del Pueblo considera acertada una constitucionalidad condicionada del aparte demandado. Dichos intervinientes observan que una interpretación de la norma puede conllevar a criminalizar la mendicidad, lo cual constituye un riesgo frente a personas vulnerables que por su condición de extrema pobreza y miseria, se ven obligados a realizar actos de mendicidad para sobrevivir. En ese orden de ideas, para la Universidad el aparte analizado presume el actuar doloso de quien ejerce la mendicidad con menores, cuando perfectamente puede ocurrir que quien mendigue en presencia de menores no pretenda explotarlos. Para la Defensoría, de conformidad con la sentencia C-040 de 2006, se debería condicionar la norma bajo el entendido "que la conducta reprochable es el ejercicio de la mendicidad utilizando o valiéndose de menores de edad, mas no la realización de tal actividad en compañía de los mismos, como quiera que esta última no constituye una conducta reprochable desde el punto de vista constitucional" -folio 92-.

En atención a los cargos formulados en el escrito de la demanda, esta Sala Plena debe resolver, en primer lugar, si el artículo 93 de la Ley 1453 
de 2011, que establece el tipo penal de explotación de menores de edad, se entiende subsumido completamente en el tipo penal de trata de personas (artículo 188-A y B del Código Penal). Determinado lo anterior, la Sala establecerá si el artículo demandado: i) vulnera el principio de igualdad, contenido en el artículo 13 de la Constitución y; ii) el derecho al debido proceso, consagrado en el artículo 29 de la Constitución. Finalmente, la Sala se detendrá en la expresión "mendigue con menores", con el fin de ilustrar la interpretación constitucional de la locución, de conformidad con el principio de debido proceso.

Con el propósito de realizar el estudio respectivo, la Sala Plena de la Corte Constitucional se referirá en esta oportunidad a los siguientes temas: (i) comparación entre los tipos penales en conflicto; (ii) concurso de conductas punibles y principios penales de interpretación; (iii) aspectos constitucionales de la mendicidad y; (iv) finalmente abordará el análisis concreto de los cargos.

\section{Análisis comparativo de los tipos penales en conflicto: explotación de menores y trata de personas}

En primer lugar, corresponde a la Sala describir los tipos penales en presunto conflicto constitucional con el fin de dilucidar individualmente su contenido, elementos y finalidad. En esa medida, esta Corporación expondrá la situación descrita en las normas de ambos tipos penales para desentrañar la calidad de los sujetos (activo y pasivo) involucrados en la conducta punible, su antijuridicidad y el bien jurídico-penal protegido.

\subsection{Explotación de menores de edad. Artículo 93, Ley 1453 de 2011}

El artículo demandado, contenido en el artículo 93, capítulo IV, relativo a "medidas para garantizar la seguridad ciudadana relacionadas con el código de la infancia y la adolescencia" de la Ley 1453 de 2011, "por medio de la cual se reforma el Código Penal, el Código de Procedimiento Penal, el Código de Infancia y Adolescencia, las reglas sobre extinción de dominio y se dictan otras disposiciones en materia de seguridad", comúnmente conocida como ley de seguridad ciudadana, tiene el siguiente tenor literal: "ARTÍCULO 93. EXPLOTACIÓN DE MENORES DE EDAD. El que utilice, instrumentalice, comercialice o mendigue con menores de edad directamente o a través de terceros incurrirá en prisión de 3 a 7 años de prisión y el menor será conducido al Instituto Colombiano de Bienestar Familiar para aplicar las medidas de restablecimientos de derechos correspondientes. /La pena se aumentará a la mitad cuando el actor sea un pariente hasta el cuarto grado de consanguinidad, segundo de afinidad o primero civil".

De la redacción anterior, es posible extraer que el sujeto activo o sujeto agente, es indeterminado ya que puede ser indistintamente cualquier persona, según la misma locución utilizada por la Ley: "el que". Por el contrario, el sujeto pasivo o titular del bien jurídico protegido es calificado, 
por cuanto la conducta típica recae particularmente en este tipo penal de manera plural o singular sobre menores de edad.

En cuanto a la acción, observa la Sala que nos encontramos ante un tipo penal de conducta alternativa toda vez que presenta cuatro verbos rectores diferentes, a saber: utilizar, instrumentalizar, comercializar o mendigar, los cuáles, de conformidad con el Diccionario de la Real Academia Española significan: utilizar es "aprovecharse de algo"; instrumentalizar es "utilizar algo o a alguien como instrumento para conseguir un fin"; comercializar es "dar a un producto condiciones y vías de distribución para su venta" y; mendigar es "pedir limosna de puerta en puerta".

Finalmente, se observa que el bien jurídico protegido en el delito de explotación de menores, aunque no se encuentre contemplado en el Código Penal dentro de un bien jurídico, obedece a la libertad individual, precisando que con respecto al delito de mendicidad con menores de edad, el legislador quiso proteger, en el texto original del artículo 231 de la Ley 599 de 2000 (derogado), el bien jurídico de la familia. Por tanto, en este delito puede coexistir más de un bien jurídico tutelado.

Finalmente, resta advertir que el tipo penal de explotación de menores de edad no contiene ingrediente subjetivo alguno.

\subsection{Trata de personas. Artículos 188-A y B del Código Penal}

El delito de trata de personas, por su parte, fue adicionado en el ordenamiento jurídico colombiano mediante Ley 747 de 2002 y consagrado en los artículos 188-A y B del Código Penal colombiano con el siguiente tenor: "ARTÍCULO 188-A. TRATA DE PERSONAS. El que capte, traslade, acoja o reciba a una persona, dentro del territorio nacional o hacia el exterior, con fines de explotación, incurrirá en prisión de trece (13) a veintitrés (23) años y una multa de ochocientos (800) a mil quinientos (1.500) salarios mínimos legales mensuales vigentes. /Para efectos de este artículo se entenderá por explotación el obtener provecho económico o cualquier otro beneficio para sí o para otra persona, mediante la explotación de la prostitución ajena u otras formas de explotación sexual, los trabajos o servicios forzados, la esclavitud o las prácticas análogas a la esclavitud, la servidumbre, la explotación de la mendicidad ajena, el matrimonio servil, la extracción de órganos, el turismo sexual u otras formas de explotación./ El consentimiento dado por la víctima a cualquier forma de explotación definida en este artículo no constituirá causal de exoneración de la responsabilidad penal".

ARTÍCULO188-B. CIRCUNSTANCIASDEAGRAVACIÓNPUNITIVA. Las penas para los delitos descritos en el artículo 188 y 188-A, se aumentará de una tercera parte a la mitad, cuando: 1. Cuando se realice en persona que padezca, inmadurez psicológica, trastorno mental, enajenación mental y trastorno psíquico, temporal o permanentemente o sea menor de 18 años. 2. Como consecuencia, la víctima resulte afectada en daño físico permanente y/o lesión psíquica, inmadurez 
mental, trastorno mental en forma temporal o permanente o daño en la salud de forma permanente. 3. El responsable sea cónyuge o compañero permanente o pariente hasta el tercer grado de consanguinidad, segundo de afinidad y primero civil. 4. El autor o partícipe sea servidor público. PARÁGRAFO. Cuando las conductas descritas en los artículos 188 y 188-A se realice sobre menor de doce (12) años se aumentará en la mitad de la misma pena".

Del mismo se extrae que cuenta con un sujeto activo indeterminado, al igual que el anterior tipo penal de explotación de menores, ya que cualquier persona puede ser el que capte, traslade, acoja o reciba a una persona. Empero, a diferencia de la explotación de menores en donde existe sujeto pasivo calificado (menores de edad), en la trata de personas el sujeto pasivo es indeterminado al cometerse sobre cualquier persona, lo que incluye no solo adultos sino también menores.

En palabras de la Sala de Casación Penal de la Corte Suprema de Justicia $^{1}$ del mismo nombre jurídico del delito se puede entender que la inflexión "trata", "conforme a sus dos principales acepciones corresponde a "Manejar algo y usarlo materialmente" o "Manejar, gestionar o disponer de algún negocio", siendo entonces de elemental lógica concluir que la acción prohibida es la de instrumentalizar o cosificar a una persona como si fuera una mercancía. Aún más, el mismo diccionario define la palabra "trata" como "Trafico que consiste en vender seres humanos".

Acerca de los verbos rectores interpreta que "captar implica atraer a alguien, ganar su voluntad; trasladar es llevar a una persona de un lugar a otro; acoger equivale a suministrarle refugio, albergue, o techo; y recibir es tomar o hacerse cargo de alguien que es entregado por un tercero. Y tales acciones pueden ejecutarse, como lo prevé la norma internacional, mediante amenazas, a través del uso de la fuerza u otras formas de coacción, como el rapto, el fraude, el engaño, o abusando del poder o confianza que se detenta sobre la persona o aprovechando de la situación de vulnerabilidad en que se halla, medios que no son exigibles cuando la víctima es un niño".

En el marco del delito de trata de personas se observa de la exposición de motivos del proyecto de ley que, "el problema de la Trata de Personas es muy grande y mucho más amplio de lo que se puede resumir (...). Colombia es el tercer país exportador de personas víctimas de la Trata a nivel mundial"2.

Se puede observar por la ubicación del tipo penal en el ordenamiento penal que la trata de personas protege el bien jurídico de la libertad y otras garantías (título III), no obstante, la trata tiene como particularidad ser un delito pluriofensivo contra la dignidad humana, que puede lesionar o poner en peligro múltiples bienes jurídicos simultáneamente como la libertad, la autonomía y la libertad sexual, entre otros. También tiene un carácter de tipo penal mixto, ya que pese a contemplar diversas modalidades de conducta, se configura con la realización de una, cualquiera de las cuatro descritas anteriormente por sus verbos rectores. 
Además, el delito de trata de personas cuenta con un ingrediente subjetivo relativo a la finalidad de explotación; el artículo claramente indica las prácticas mediante las cuales, regularmente, el sujeto activo de la acción somete al sujeto pasivo en procura de obtener provecho económico o cualquier otro beneficio para sí o para un tercero, a saber, la explotación de la prostitución ajena u otras formas de explotación sexual, los trabajos o servicios forzados, la esclavitud o las prácticas análogas a la esclavitud, la servidumbre, la explotación de la mendicidad ajena, el matrimonio servil, la extracción de órganos, el turismo sexual u otras formas de explotación. Así, si bien el tipo penal no requiere que se obtenga el fin de explotar a la víctima para la configuración del tipo, por cuanto basta la realización de alguno de los verbos rectores para la configuración del delito, es cierto que para que el peligro ocasionado con la conducta del sujeto activo sea considerado como delito, debe existir un riesgo inminente, próximo, real y efectivo de que el hecho de vulneración ocurra.

Adicionalmente, respecto a la distinción dogmática entre el delito de trata de personas y otros delitos, o la llamada "confusión típica" planteada por la demandante, es claro que la trata de personas por su amplitud se puede presentar en concurso con otras conductas punibles. "La línea divisoria entre el delito de trata de personas en comparación con otros tipos penales es muy tenue, por lo que en muchos casos no resulta tarea fácil hacer la adecuación típica"3. De igual manera, lo reconoce jurisprudencia de la Sala Penal de la Corte Suprema de Justicia, "la Sala estima oportuno hacer énfasis en que el sujeto activo (plural o individual) de la conducta punible de trata de personas, al desarrollar el iter criminal, puede, y de hecho así ocurre en la práctica, incurrir en diferentes comportamientos lesivos de otros bienes jurídicamente tutelados, como por ejemplo, el secuestro, la falsificación de documentos, etc., sin que por ello desaparezca el fin último perseguido y concretado, esto es, la mercantilización o comercio de un ser humano, ni el real o efectivo concurso de tipos penales, cuya adecuada y completa atribución corresponde hacerla al órgano encargado de la persecución penal"4.

Mediante Ley 800 de 2003, el Legislador colombiano aprobó el “Protocolo para Prevenir, Reprimir y sancionar la Trata de Personas, especialmente Mujeres y Niños, que complementa la Convención de las Naciones Unidas contra la Delincuencia Organizada Transnacional", adoptados por la Asamblea General de las Naciones Unidas el quince (15) de noviembre de dos mil (2000). El literal a) del artículo $3^{\circ}$ de este Protocolo entiende como definición de la trata de personas "la captación, el transporte, el traslado, la acogida o la recepción de personas, recurriendo a la amenaza o al uso de la fuerza $u$ otras formas de coacción, al rapto, al fraude, al engaño, al abuso de poder o de una situación de vulnerabilidad o a la concesión o recepción de pagos o beneficios para obtener el consentimiento de una persona que tenga autoridad sobre otra, con fines de explotación. Esa explotación incluirá, como mínimo, la explotación de la prostitución ajena u otras formas de explotación sexual, los trabajos o servicios forzados, la esclavitud o las prácticas análogas a la esclavitud, la servidumbre o la extracción de órganos". 
Con importancia para el caso objeto de estudio, el literal c) de la misma disposición señala que "la captación, el transporte, el traslado, la acogida o la recepción de un niño con fines de explotación se considerará "trata de personas" incluso cuando no se recurra a ninguno de los medios enunciados en el apartado a) del presente artículo".

\subsection{Conclusión preliminar}

Con todo lo dicho, la Sala concluye que los delitos en comparación de explotación de menores, contenido en el artículo 93 de la Ley 1453 de 2011 y el delito de trata de personas estipulado en el artículo 188-A del Código Penal no tienen identidad típica por cuanto se diferencian en cuatro puntos cardinales. En primer lugar, por los sujetos pasivos de ambos tipos penales; en el artículo demandado -explotación de menores-, el sujeto pasivo es determinado al recaer exclusivamente sobre menores de edad, mientras que en la trata de personas el sujeto pasivo puede ser cualquier persona, es decir, es indeterminado. En segundo lugar, aunque ambos delitos comprenden conductas alternativas, los verbos rectores son completamente distintos: la explotación de menores reprocha al que utilice, instrumentalice, comercialice o mendigue con menores de edad, por su parte, la trata pena a quien capte, traslade, acoja o reciba a cualquier persona. En tercer lugar, el tipo penal de trata de personas se diferencia de la explotación de menores al contener un ingrediente subjetivo o un carácter intencional distinto del dolo que se emplea para describir la conducta, en este caso, el delito de trata prevé como elemento adicional una finalidad de explotación, inexistente en el delito de explotación de menores. Finalmente, el delito de trata de personas presenta modalidades de agravación ausentes en el delito de explotación de menores.

\section{Concurso de conductas punibles y principios interpretativos en materia penal}

La Ley 599 de 2000 "por la cual se expide el Código Penal", reguló en el título III, capítulo único, "de la conducta punible", el concurso de conductas punibles en el supuesto que mediante una o varias conductas punibles se infrinjan varias disposiciones de la ley o varias veces la misma disposición: "ARTICULO 31. CONCURSO DE CONDUCTAS PUNIBLES. El que con una sola acción $u$ omisión o con varias acciones $u$ omisiones infrinja varias disposiciones de la ley penal o varias veces la misma disposición, quedará sometido a la que establezca la pena más grave según su naturaleza, aumentada hasta en otro tanto, sin que fuere superior a la suma aritmética de las que correspondan a las respectivas conductas punibles debidamente dosificadas cada una de ellas. / En ningún caso, en los eventos de concurso, la pena privativa de la libertad podrá exceder de sesenta (60) años. /Cuando cualquiera de las conductas punibles concurrentes con la que tenga señalada la pena más grave contemplare sanciones distintas a las establecidas en ésta, dichas consecuencias jurídicas se tendrán en cuenta a efectos de hacer la tasación de la pena correspondiente. PARAGRAFO. En 
los eventos de los delitos continuados y masa se impondrá la pena correspondiente al tipo respectivo aumentada en una tercera parte".

Así, el concurso efectivo de tipos se presenta cuando uno o varios comportamientos de la misma persona coetáneamente encuadran en varios tipos penales que, sin excluirse el uno del otro, deben aplicarse simultáneamente.

Por ello, la teoría del concurso tiene como finalidad determinar conforme a la ley vigente, la teoría de unidad y pluralidad de conductas y tipicidades y los criterios de política criminal como proporcionalidad, razonabilidad, necesidad, autonomía del bien jurídico, non bis in ídem e igualdad material, una sanción punitiva adecuada que refleje el verdadero grado del injusto penal y la culpabilidad existente, según las distintas estructuras de pluralidad normativa de tipos penales.

Así lo ha entendido la Corte Constitucional:

(...) "Rasgos determinantes de la figura del concurso de conductas punibles son la unidad de sujeto activo; la unidad o pluralidad de acciones $u$ omisiones; la realización de varios tipos penales, o varias veces la misma infracción; y la unidad de proceso" ${ }^{2}$.

De esta manera, será tarea del funcionario judicial precisar si la conducta prevista en la ley punible encaja de manera directa en un tipo penal determinado. No obstante, en el proceso de adecuación típica del comportamiento examinado, puede suceder que una misma persona realice una conducta penalmente relevante susceptible de ubicarse en dos o más tipos penales, o un número plural de conductas que encajen en idéntico supuesto de hecho o en varios; problemática penal que es denominada y resuelta por la doctrina en la teoría de los concursos o unidad y pluralidad de conductas típicas, que pasa la Sala a precisar sucintamente:

El concurso material o real se presenta cuando una persona realiza una pluralidad de acciones independientes, susceptibles de ser encuadradas en uno o en varios tipos penales. El Código Penal lo señala expresamente al contemplar el supuesto relativo a que "con varias acciones $u$ omisiones infrinja varias disposiciones de la ley penal o varias veces la misma disposición". En el caso que las acciones independientes se circunscriban a un mismo tipo penal, surge el concurso material homogéneo, por el contrario, cuando un mismo agente incurre en diversos tipos penales, acontece el concurso material heterogéneo.

En palabras de Reyes Echandía, "esta modalidad se presenta cuando varias acciones $u$ omisiones realizadas por el mismo agente con finalidades diversas producen una pluralidad de violaciones jurídicas y, por lo mismo, encuadran en varios tipos penales, o varias veces en el mismo tipo"6.

En criterio de la Sala de Casación Penal de la Corte Suprema de Justicia, el concurso material es, "el que se presenta cuando una misma persona comete varios delitos susceptibles de encajar en un mismo precepto penal o en varios, los cuales 
deben guardar una completa autonomía o independencia tanto en el plano subjetivo como en el objetivo. En este caso no hay unidad de acción sino acciones u omisiones independientes y se aplican los tipos respectivos puesto que no son excluyentes"7. Este tipo de concurso es considerado como la modalidad natural de los concursos, pues naturalmente varias acciones pueden dar lugar a varios delitos.

Este concurso implica una pluralidad de acciones independientes o separadas, sin vínculo alguno entre sí y con momentos diferenciables. Esta forma de proceder genera una multiplicidad de delitos que lesionan por más de una vez uno o varios bienes jurídicos.

El concurso ideal o formal, por su parte, se diferencia del anterior por la unidad de acción, en tanto el agente realiza una única acción que configura varios delitos, los cuales resultan aplicables de manera conjunta, "hay concurso ideal o formal cuando una acción se adecúa a varias figuras típicas que no se excluyen entre si"s. Por tanto, el concurso ideal o formal es el único caso de concurso de tipos penales en una acción y conlleva una pluralidad de tipos penales.

El Código Penal consagra este tipo de concurso de manera expresa, "el que con una sola acción u omisión infrinja varias disposiciones de la ley penal". El Profesor Posada Maya, expone como exigencias del concurso ideal: la unidad e identidad de conducta, la múltiple desvaloración penal de la conducta, la uniformidad del sujeto activo y la unidad o pluralidad de sujetos pasivos?.

De lo anterior, la Sala concluye que la dogmática del derecho penal se ha ocupado de establecer supuestos y fórmulas de resolución para situaciones que deben ser investigadas y juzgadas en un mismo proceso; así, cuando el autor mediante una misma acción ejecuta al mismo tiempo una pluralidad de tipos penales (concurso ideal o formal) o bien cuando el autor presenta una pluralidad de acciones independientes, susceptibles de ser adecuadas a uno o varios tipos penales (concurso real o material), se configura en la práctica judicial un concurso de conductas punibles (art. 31, Código Penal), caso en cual, el funcionario judicial competente deberá imponer la pena más grave según su naturaleza, acumulable hasta en otro tanto.

A su turno, el concurso aparente se configura cuando ilusoriamente existe una concurrencia de tipos penales sobre una conducta. Por ejemplo, prima facie, se encuadra el caso en un concurso ideal, pero tras un estudio detenido de la tipicidad se llega a la conclusión de que no es así, por ello, se suele denominar este concurso como concurrencia de leyes, pues es lo que sucede: dos o más normas penales son aplicables aparentemente al caso concreto por una única acción.

Se entiende doctrinalmente por concurso aparente, "el fenómeno en virtud del cual una misma conducta parece subsumirse a la vez en varios tipos penales diversos y excluyentes, de manera que el juez, no pudiendo aplicarlo coetáneamente 
sin violar el principio de non bis in ídem, debe resolver concretamente a cuál de ellos se adecua el comportamiento en estudio"10.

En el concurso aparente de delitos -que bien se ha clarificado como un aparente concurso-, una misma situación de hecho desplegada por el autor pareciera adecuarse a las previsiones de varios tipos penales, cuando en verdad una sola de estas normas es aplicable al caso en concreto, atendiendo razones de especialidad, subsidiaridad o consunción, ya que las demás resultan impertinentes por defectos en su descripción legal o porque las hipótesis que contienen van más allá del comportamiento del justiciable ${ }^{11}$.

Se trata, por ende, de un formal acomodamiento de la conducta a dos disímiles descripciones que la punen en la ley, solo que el análisis de sus supuestos bajo aquellos postulados generales de contenido jurídico elaborados por la doctrina, posibilitan descartar su material concurrencia, por entrar, preferiblemente, uno de ellos a colmar en los distintos órdenes los principios que los regulan; con mayor amplitud en sus características estructurales, o en el desvalor de conducta que es predicable o en el nivel de afectación del bien jurídico que es objeto de tutela con su contemplación legal.

Las hipótesis de concurso aparente se presentan generalmente entre disposiciones de un mismo ordenamiento que suele ser el Código Penal y es común que dichas normas pertenezcan a la parte especial de dichos ordenamientos porque es allí donde se suele hacer la descripción de los distintos delitos. Sin embargo, también pueden predicarse concursos aparentes con relación a distintos ordenamientos, piénsese por ejemplo en normas penales militares y normas penales ordinarias semejantes. Así, suele existir concurso aparente entre peculado y hurto, hurto y estafa, homicidio y lesiones personales, homicidio simple y homicidio agravado, entre otros, hipótesis en las cuales las normas señaladas recogen el comportamiento investigado pero por tratarse de una sola acción solo puede ser aplicada una de ellas en respeto de los principios constitucionales de debido proceso y non bis in ídem ${ }^{12}$.

Esta problemática penal se circunscribe como una manifestación de la unidad delictiva que como característica relevante posee la de que existe pluralidad de tipos penales que efectivamente concurren en la descripción de la conducta única investigada. En ese orden de ideas, el concurso aparente se soluciona cuando el juzgador selecciona entre los varios tipos que realmente concurren cuál es el que debe ser aplicado por existir un solo delito, la figura se reduce entonces a un problema de interpretación de la ley penal que nada tiene que ver con los concursos real o ideal, en los cuales lo que existe no es una simple multiplicidad de tipos penales sino una pluralidad de hechos punibles. En efecto, aceptado que el fundamento del concurso aparente radica en el respeto al non bis in ídem, es decir, habida cuenta que la figura existe como un mecanismo para evitar que una sola acción sea valorada o sancionada varias veces, es innegable que lo que con ella se busca es que ante la presencia de un solo delito no se apliquen a su autor varios tipos penales que supondrían una pluralidad de sanciones. 
Para Reyes Alvarado, "plantear que el concurso aparente es una manifestación de la unidad delictiva en la cual varias normas describen esa misma conducta hace pensar en que no es correcto que reconociendo de antemano la existencia de una sola acción que sólo puede generar una sanción penal, puedan concurrir una pluralidad de disposiciones que comprendan ese comportamiento dentro de su descripción; pues bien, esta afirmación es correcta y pone de relieve que lo que se ha venido denominando concurso aparente de hechos punibles es en la mayoría de los casos el producto de fallas legislativas que suelen derivarse de la equivocada pretensión legislativa de sancionar conductas de acuerdo con la forma de lesión del bien jurídico protegido en lugar de tener en cuenta solo la efectiva afectación al bien jurídico y el grado en que dicha lesión se haya producido"13 -negrilla fuera de texto-.

Algunos autores sostienen que este fenómeno se confunde con el concurso ideal; sin embargo, la diferencia estriba en que en el concurso aparente una sola acción cometida por una misma persona parece adecuarse en dos o más tipos penales excluyentes, esto es, hay un único sujeto activo, unidad de acción y pluralidad de tipos. En el concurso ideal los tipos penales a los cuales se encuadra el comportamiento humano concurren y, por tanto, se aplican simultáneamente al caso. Por ello, mientras en el concurso ideal hay acumulación jurídica de penas, en el concurso aparente se impone la pena prevista en el tipo que resulte aplicable.

La jurisprudencia de la Sala de Casación Penal de la Corte Suprema de Justicia ha reiterado que "el concurso aparente de tipos penales tiene como presupuestos básicos (i) la unidad de acción, esto es, que se trata de una sola conducta que encuadra formalmente en varias descripciones típicas, pero que realmente sólo encaja en una de ellas, (ii) que la acción desplegada por el agente persiga una única finalidad y (iii) que lesione o ponga en peligro un solo bien jurídico, de manera tal que la ausencia de uno de tales elementos conduce a predicar el concurso real y no el aparente"14.

Adicionalmente, esta misma Corporación ${ }^{15}$ ha destacado, coincidiendo con la doctrina, que la solución racional del concurso aparente de tipos -para obviar el quebranto del principio non bis in ídem-, en el sentido de seleccionar la norma que resulte adecuada, impone la aplicación de los principios de especialidad, subsidiariedad y consunción, ya que uno solo de ellos ha de ser llamado a ser aplicado, de lo contrario se violaría el principio de non bis in ídem constitucional, de acuerdo con el cual un mismo comportamiento no puede ser investigado o sancionado dos veces.

Dada la dificultad que se presenta cuando hay concurso aparente para efectos de realizar una correcta adecuación típica de la conducta, la doctrina ha formulado algunos principios interpretativos que ilustran a la demandante sobre los cargos formulados y facilitan a los jueces la forma de proceder en un caso de adecuación típica complejo. Para la Sala estos principios pueden ser usados por el juzgador como parámetro interpretativo en casos de difícil definición al encuadrar correctamente el tipo penal aplicable. 
Así lo ha reconocido esta Corte, en sentencia C-121 de 2012 “(...) De cualquier modo, frente al concurso aparente de normas o tipos penales, el operador jurídico, en el ámbito de su autonomía, cuenta con herramientas interpretativas como los principios de especialidad, subsidiariedad, consunción o alternatividad, cuyo cometido es enfrentar, en el plano judicial, eventuales riesgos de vulneración del non bis in idem".

El principio de especialidad se deriva de la locución latina: "lex especialis derogat lex generalis", adagio jurídico popular según el cual la ley especial debe ser aplicada de preferencia sobre la general, cuando un tipo penal reproduce en forma estructural los elementos de otro. Esto puede ocurrir cuando varias normas penales comprenden dentro de su descripción un comportamiento pero en diferente grado, así mientras una de ellas lo hace de forma general otra lo hace de manera específica y, por tanto, ésta última resulta aplicable.

Según la Corte Suprema de Justicia -Sala de Casación Penal-, "una norma penal es especial cuando describe conductas contenidas en un tipo básico, con supresión, agregación, o concreción de alguno de sus elementos estructurales. Por consiguiente, para que un tipo penal pueda ser considerado especial respecto de otro, es necesario que se cumplan tres supuestos fundamentales: 1) que la conducta que describe esté referida a un tipo básico; b) Que entre ellos se establezca una relación de género a especie; $y, c)$ Que protejan el mismo bien jurídico. Si estos presupuestos concurren, se estará en presencia de un concurso aparente de tipos, que debe ser resuelto conforme al principio de especialidad: lex specialis derogat legi generali"16.

Dicho principio ha sido consagrado legalmente, ya que la Ley 57 de 1887, artículo $5^{\circ}$, prevé que "si en los códigos que se adoptaren se hallaren algunas disposiciones incompatibles entre sí, se observarán en su aplicación las siguientes reglas: $1^{a}$ La disposición relativa a un asunto especial prefiere a la que tenga carácter general".

El principio de subsidiariedad surge de la locución latina: "lex primaria derogat legis subsidiariae" e indica que el tipo subsidiario se inaplica ante el principal. La subsidiariedad puede aplicarse bien de manera expresa cuando el legislador se encarga de señalarla, o de forma tácita la cual debe deducirse de la ley. Según Velásquez, "este postulado opera cuando el analista debe resolver concursos aparentes de tipos motivados por la existencia de figuras que describen diversos grados de lesión o afectación de los bienes jurídicos, desde los más leves hasta los más graves, de tal manera que el supuesto de hecho subsidiario es interferido por el principal"17.

Para la Sala de Casación Penal de la Corte Suprema de Justicia, "un tipo penal es subsidiario cuando solo puede ser aplicado si la conducta no logra subsunción en otro que sancione con mayor severidad la transgresión del mismo bien jurídico. Se caracteriza por ser de carácter residual, y porque el legislador, en la misma consagración del precepto, advierte generalmente sobre su carácter accesorio 
señalando que solo puede ser aplicado si el hecho no está sancionado especialmente como delito, o no constituye otro ilícito, como acontece, por ejemplo, con el abuso de autoridad (art.152, modificado por el 32 de la ley 190 de 1995), o el empleo o lanzamiento de sustancias u objetos peligrosos (artículo 198 ejusdem), entre otros".

"De acuerdo con lo expresado, dos hipótesis pueden llegar a presentarse en el proceso de adecuación típica frente a disposiciones subsidiarias: 1) Que la conducta investigada corresponda a la del tipo penal subsidiario exclusivamente; y, 2) Que simultáneamente aparezca definida en otro tipo penal de mayor jerarquía (básico o especial) que protege el mismo bien jurídico. En el primer supuesto ningún inconveniente se presenta, pues siendo una la norma que tipifica la conducta, se impone su aplicación. En el segundo, surge un concurso aparente de tipos que debe ser resuelto con exclusión de la norma accesoria, en virtud del principio de subsidiariedad".

El principio de la consunción es aquel que interviene cuando un tipo penal determinado absorbe en sí el desvalor de otro y por tanto excluye a éste de su función punitiva. Dicho principio se enuncia de la siguiente manera: "lex consumens derogat legi consumptae". En ese sentido, frente a dos supuestos de hecho se prefiere el más grave, amplio y complejo el cual absorbe al menos lesivo.

La Corte Suprema de Justicia ha considerado respecto a este principio que "se tiene el tipo penal complejo o consuntivo, que por regla general se presenta cuando su definición contiene todos los elementos constitutivos de otro de menor relevancia jurídica. Se caracteriza por guardar con éste una relación de extensióncomprensión, y porque no necesariamente protege el mismo bien jurídico. Cuando esta situación ocurre, surge un concurso aparente de normas que debe ser resuelto en favor del tipo penal de mayor riqueza descriptiva, o tipo penal complejo, en aplicación del principio de consunción.

(...) En virtud del principio de consunción -que no se ocupa de una plural adecuación típica de la conducta analizada- si bien los delitos que concursan en apariencia tienen su propia identidad y existencia, el juicio de desvalor de uno de ellos consume el juicio de desvalor del otro, y por tal razón sólo se procede por un solo comportamiento ${ }^{18}$. Es aplicable la consunción cuando entre los dos punibles existe una relación de menos o más, o de imperfección a perfección, como ocurre en los llamados delitos progresivos, no cuando existe una simple conexidad ${ }^{19}$ ".

Finalmente, el principio de alternatividad que se aplica de manera accesoria a los anteriores, puede darse de manera propia e impropia. La alternatividad impropia hace referencia a la hipótesis en la cual el legislador ha descrito en dos tipos penales diversos la misma conducta, de tal manera que siendo idénticas las descripciones puede afirmarse que las varias disposiciones actúan como círculos secantes; de acuerdo con esta concepción doctrinal dicha forma de alternatividad se resolverá seleccionando la norma que prevea la sanción más alta aplicable. Según Reyes Alvarado ésta forma de alternatividad "trata de plurales descripciones de una misma conducta que a 
veces pueden aparecer dentro de una misma ley incluso con sanciones diversas; sin embargo debe reconocerse que no resulta frecuente que ello ocurra y en las pocas oportunidades en que se presente dicha hipótesis sólo puede obedecer a manifiestos errores legislativos" 20 .

La alternatividad propia se presenta cuando dos o más normas penales protegen el mismo bien jurídico pero contra dos formas diversas de lesión. En este tipo de interpretación de la ley ocurre que los tipos penales se interfieren; cuentan con espacios comunes, que concentran los problemas de interpretación frente al principio de non bis in ídem y con espacios excluyentes que suponen la imposibilidad de aplicar de forma simultánea los supuestos de hecho de concurso efectivo.

\section{Aspectos constitucionales de la mendicidad}

En este punto la Sala Plena se detendrá en la mendicidad, con el objeto de decantar la evolución legislativa del delito, cuándo nació, fue derogado y cuál es la interpretación auténtica del Legislador y la Corporación al respecto.

La mendicidad y el tráfico de menores fue una conducta punible inicialmente reprochada en la Ley 599 de 2000 o Código Penal, así, se consagró como un delito autónomo de lesión al bien jurídico de la familia, cuando estuvo contenido en el título VI de dicho estatuto penal. El artículo 231, actualmente derogado, penaba entonces "el que ejerza la mendicidad valiéndose de un menor de doce (12) años o lo facilite a otro con el mismo fin, o de cualquier otro modo trafique con él. La pena se aumentará de la mitad a las tres cuartas partes cuando: 1. Se trate de menores de seis (6) años. 2. El menor esté afectado por deficiencias físicas o mentales que tiendan a producir sentimientos de conmiseración, repulsión u otros semejantes".

En sentencia C-1068 de 2002 (unánime), la Corte, al estudiar una demanda presentada contra la expresión "de doce (12) años", contenida en el artículo anteriormente citado, decidió declararla inexequible por cuanto no existía justificación constitucional para excluir a los mayores de esta edad (12 años) y menores de 18 años de la protección penal. No obstante, la Corporación aprovechó esta oportunidad para sentar una posición respecto a la mendicidad propia, considerando que cuando se ejerce de manera personal y autónoma, no es un delito, "sea lo primero señalar que el artículo 231 de la ley 599 de 2000 no establece como tipo penal el ejercicio de la mendicidad para sí, de manera autónoma y personal; vale decir, prescindiendo de la utilización del agente intermediario alli descrito, no constituye conducta punible el pedir limosna por decisión personal y valiéndose de su propia corporeidad y destreza. En otras palabras, con la salvedad expuesta, en Colombia no es delito pedir limosna". Más adelante señaló, "la mendicidad resulta penalmente sancionable por la forma en que se ejerce y no por su naturaleza misma, en orden a salvaguardar los derechos fundamentales de los niños y la entidad misma de la familia en tanto núcleo fundamental de la sociedad". 
Ahora bien, con la aprobación de la Ley 747 de 2002 se hicieron algunas reformas y adiciones al Código Penal (Ley 599 de 2000); se creó un nuevo tipo penal de trata de personas (arts. 188 A y B) y se derogó el citado artículo 231 que consagraba el delito de mendicidad y tráfico de menores, entre otras disposiciones.

En la exposición de motivos ${ }^{21}$ de esta ley, tramitada en la Cámara de Representantes bajo el proyecto de ley 173 de 2001, "por medio de la cual se hacen unas reformas y adiciones al Código Penal (Ley 599 de 2000), se crea el Capítulo "Trata de Personas" y se dictan otras disposiciones", el legislativo consideró que hasta ese momento todo lo referente a la trata de personas se encontraba desarrollado de manera insuficiente únicamente en los artículos 215 (trata de personas) y 231 (mendicidad y tráfico de menores) del Código Penal:

\begin{abstract}
"El nuevo Código Penal en su artículo 215 tipifica la Trata de Personas con fines de prostitución y en el 231 se penaliza el tráfico de personas menores de doce años con fines de mendicidad. Teniendo en cuenta las diversas modalidades que está adoptando este flagelo a nivel nacional e internacional, se ajusta la tipicidad del mismo a la definición de ¿Trata de Personas; -sic- internacionalmente adoptada, adicionando un artículo nuevo que penaliza la comisión de este delito con fines de servidumbre, matrimonios serviles, trabajo forzoso u obligatorio, esclavitud y tráfico de personas en cualquiera de sus formas dentro o fuera del país"22. Negrita fuera de texto.
\end{abstract}

Esta posición del legislador se hizo más explícita en la ponencia para primer debate al proyecto de ley en el Senado de la República, presentada por el Senador Ponente Darío Martínez Betancourt, en la cual se resaltó que la mendicidad por estado de necesidad no debe ser punible. La Sala transcribe a continuación el aparte relevante de la ponencia para este juicio de constitucionalidad:

"La realidad de aquel que se encuentra en el parque con los menores, con este tipo no requiere que sea aprehendido en flagrancia, como el tipo penal es rico en verbos se puede fácilmente encuadrar la conducta en el recorrido criminal.

Además que sin equivocarme, el sentir de la iniciativa no va dirigido a los pobres que tienen que hacerlo por necesidad, sino que va dirigido a los explotadores de menores que los obligan a la mendicidad. Esa realidad está descrita en el artículo 188A del proyecto, y es considerada como una trata de personas.

Dejemos que los alcaldes, el Estado, resuelvan de una forma social, o administrativa la realidad de la mendicidad de aquellos que acuden a ella para su sustento. No volquemos esa política social que reclama nuestra Nación, en una norma penal. No permitamos que nuestro trabajo serio, se pierda al dejar en vigencia el artículo 231 de la Ley 599 de 2000 y que el proyecto aprobado en la honorable Cámara, no se aplique. No dejemos puertas traseras abiertas para que burlen la ley.

Nos encontraríamos realmente en un limbo jurídico y legislar para que la norma sea burlada es mejor no hacerlo. 
Y por último, la mendicidad predicada en el artículo 188A, no es limitada, no solo protege a los menores de doce años sino también a los menores en general, los discapacitados, a los enfermos mentales. ${ }^{23 "}$ "negrilla fuera de texto.

Posteriormente, la Corte Constitucional se pronunció nuevamente acerca de la mendicidad, en sentencia C- 040 de 2006, declaró inexequibles parcialmente los artículos $1^{\circ}$ y $4^{\circ}$ del Decreto ley 1136 de 1970 y reiteró la posición descrita en la sentencia precitada C-1068 de 2002, agregando que, "la mendicidad ejercida por una persona de manera autónoma y personal, sin incurrir en la intervención de un agente intermediario a través de la trata de personas señalada; en momento alguno constituye delito, no es una conducta reprochada en un Estado Social de derecho como el nuestro y por lo tanto no debe ser sancionada".

En dicho fallo también se precisó que la mendicidad propia ni siquiera tiene el carácter de contravención, al haber sido excluida o derogada del ordenamiento jurídico:

\footnotetext{
"En consecuencia, no siendo la mendicidad un delito ni tampoco una contravención, esta Corporación constata que no existe entonces un reproche jurídico por tal ejercicio. Por consiguiente, el establecer una sanción a una conducta no reprochada jurídicamente vulnera el artículo 29 de la Constitución que establece el principio de legalidad. El artículo $1^{\circ}$ viola la Constitución por ser una norma indeterminada, ya que no señala cuál es la asistencia que se presta al mendigo. Es además una norma desproporcionada ya que por el solo hecho de ser mendigo sin haber realizado ningún otro acto, la persona puede ser recluida en asilo, hospital o clínica. Atenta contra la libertad del artículo 13 de la Constitución ya que se les recluye contra su voluntad. Atenta también contra la dignidad, ya que utiliza un lenguaje que cosifica al mendigo al disponer que será "entregado" como si el mendigo no fuera persona, sino cosa".
}

La sentencia además destaca que el principio fundamental de Estado Social de Derecho, contenido en el artículo $1^{\circ}$ de la Constitución Política, como estructura básica de nuestro ordenamiento constitucional, implica que el Estado tiene un deber constante con los ciudadanos consistente en proporcionarles bienestar, lo cual se traduce en proveer un mínimo de bienes y servicios, materiales y espirituales al alcance de los individuos y propender porque todos los colombianos tengan empleo, seguridad social, vivienda, educación, alimentos, etc.

Finalmente, la Ley 1453 de 2011, en su artículo 93, sin motivación en el trámite legislativo, estableció el tipo penal de "explotación de menores", que reprocha nuevamente a quien "mendigue con menores de edad" con una pena de 3 a 7 años.

De las anteriores consideraciones y precedentes constitucionales, surgen tres conclusiones claras para la Sala Plena: i) la mendicidad es sancionable únicamente cuando se instrumentaliza o utiliza a otra persona o un menor para obtener lucro. Empero, desde el punto de vista 
constitucional -en virtud de la cláusula de Estado Social de Derechono existe justificación válida para reprochar penalmente la mendicidad propia o en compañía de un menor de edad, que compone parte del núcleo familiar; ii) este tipo de mendicidad propia con menores de edad, no tiene la intención de explotar o instrumentalizar al menor sino la finalidad de que grupos familiares en debilidad manifiesta satisfagan necesidades mínimas del ser humano y permanezcan unidos; iii) resulta evidente que la intención del legislador fue sancionar de manera autónoma los actos en los que se utilice un menor para mendigar, sin proscribir formas de mendicidad propia.

\section{Análisis concreto de los cargos}

A continuación procede la Sala Plena de la Corte Constitucional a resolver los cargos. Para ello analizará si el contenido normativo demandado del artículo 93 de la Ley 1453 de 2011, en comparación con el delito de trata de personas, establecido en los artículos 188-A y B del Código Penal, quebranta los principios de igualdad y debido proceso. Posteriormente, decidirá acerca de la constitucionalidad de la expresión "mendigue con menores de edad", explícitamente acusada por la demandante -folios 14 y 15-, como vulneratoria del debido proceso y del principio de legalidad.

\subsection{El artículo 93 contenido en la Ley 1453 de 2011 no desconoce el principio de igualdad}

El principio de igualdad contenido en el artículo 13 constitucional constituye un fundamento insustituible en el ordenamiento jurídico colombiano, que pretende principalmente reconocer dos situaciones: que todos los seres humanos tienen derecho a exigir de las autoridades públicas un mismo trato ante situaciones iguales, o un trato desigual para quienes se hallen en situaciones disímiles.

En esa medida, al abordar un juicio de igualdad la Corte ha establecido que lo primero que debe estudiar el juez constitucional es si, en relación con un criterio de comparación -tertium comparationis-, las situaciones de los sujetos o normas bajo revisión son similares, ya que si se encuentra que son claramente distintas, no procede el test de igualdad. Por el contrario, en caso de predicarse un patrón de igualdad, el juez deberá entrar a analizar la razonabilidad, proporcionalidad, adecuación e idoneidad del trato diferenciado que consagra la norma acusada, exponiendo los fines perseguidos, los medios empleados para alcanzarlo y la relación medio-fin.

El caso que ocupa en esta oportunidad a la Corte Constitucional, no logra superar la totalidad del juicio de procedencia respecto al principio de igualdad por cuanto la explotación de menores regulada en el artículo 93 de la Ley 1453 de 2011 demandado, es claramente diferenciable del 
delito de trata de personas contenido en los artículos 188-A y B del Código Penal, por las siguientes consideraciones: i) los sujetos pasivos: en el delito de explotación de menores el sujeto pasivo es calificado, exclusivamente protege a los menores de edad, mientras que en el delito de trata de personas el sujeto pasivo es indeterminado; ii) los verbos rectores: en la conducta punible demandada se emplean los verbos: utilizar, instrumentalizar, comercializar y mendigar, los cuales son completamente disímiles a los verbos rectores consagrados en el delito de trata de personas, a saber: captar, trasladar, acoger o recibir; iii) el delito de trata de personas presenta un elemento subjetivo, distinto del dolo -"con fines de explotación"-, mientras el delito de explotación de menores no supone en el autor un determinado propósito, intención, motivación o impulso que se adicione al dolo y; iv) el delito de trata de personas presenta una modalidad agravada en el artículo 188-B, por ejemplo, cuando la conducta se realice en persona menor de 18 o 12 años, inexistente en el delito de explotación de menores.

Como corolario de lo anterior, a prima facie existen cuatro desigualdades relevantes en la tipicidad de las conductas punibles objeto de examen, que impiden a la Sala Plena de la Corporación adelantar un juicio o test de igualdad sobre la generalidad de la norma acusada. Contrario a lo expresado por la demandante, se tiene que el delito de explotación de menores, al ser confrontado con el delito de trata de personas, es indiscutiblemente distinto, por cuanto, se reitera, contiene un sujeto pasivo calificado dirigido exclusivamente a los menores de edad, conductas típicas descritas que no se traslapan por los verbos rectores en comparación, ausencia de un ingrediente subjetivo en el tipo, así como de modalidades de agravación.

Además, al profundizar sobre el ingrediente subjetivo del tipo en el delito de trata de personas, este se caracteriza -siguiendo la clasificación de Mezger- por ser un tipo penal de intención que se consuma formalmente antes de la lesión o peligro del bien jurídico, es decir, el tipo penal de trata de personas tiene un resultado cortado: "fines de explotación", lo cual indica que se prescinde del acaecimiento del resultado para tipificar la conducta como punible. Así, a diferencia de lo establecido en el delito de explotación de menores, en la trata de personas la conducta es típica así no se concrete el resultado, intención o finalidad de explotación.

Todo lo anterior, conlleva a la Sala a concluir que el delito de trata de personas no se puede entender subsumido en el tipo penal demandado o viceversa, habida cuenta que en el delito en comparación el reproche penal recae en el solo hecho de captar, trasladar, acoger o recibir a una persona, dentro del territorio nacional o hacia el exterior, sin que seas necesarias las finalidades o modalidades de explotación. Contrario sensu, al analizar el delito de explotación de menores se observa que este requiere obligatoriamente esa 
finalidad de explotación materializada en la utilización, instrumentalización, comercialización o mendicidad del menor de edad.

Adicionalmente, la conducta típica demandada no representa un delito pluriofensivo, de carácter transnacional, conocido ampliamente como la nueva forma de esclavitud moderna. Tampoco requiere indefectiblemente de un movimiento o traslado de personas perpetrado por un grupo estructurado en el tiempo. En ese sentido, los tipos penales en comparación son completamente autónomos y se ubican en contextos de criminalidad distinta ya que operan en circunstancias de modo determinadas. Si bien los dos parten de la instrumentalización del ser humano (en este caso los niños), la trata de personas despliega su origen en el contexto internacional con un grado de lesividad mucho mayor, comoquiera que implica un tráfico de personas organizado por redes criminales a escala nacional o internacional en las que el ser humano se convierte en mercancía; de ahí que la reacción del legislador sea más severa. El tipo penal demandado -explotación de menores-, tiene un origen estrictamente nacional, menor riqueza descriptiva e inferior lesividad, además su finalidad concreta radica en brindar una protección exclusiva a los menores de edad en un contexto de seguridad ciudadana.

Esto, en enmarca en la intención del legislador, quien al establecer la trata de personas en la Ley 747 de 2002, pretendió acoger la definición de la trata de personas internacionalmente adoptada para desarrollar la figura:

"El nuevo Código Penal en su artículo 215 tipifica la Trata de Personas con fines de prostitución y en el 231 se penaliza el tráfico de personas menores de doce años con fines de mendicidad. Teniendo en cuenta las diversas modalidades que está adoptando este flagelo a nivel nacional e internacional, se ajusta la tipicidad del mismo a la definición de ¿Trata de Personas $i$-sicinternacionalmente adoptada, adicionando un artículo nuevo que penaliza la comisión de este delito con fines de servidumbre, matrimonios serviles, trabajo forzoso u obligatorio, esclavitud y tráfico de personas en cualquiera de sus formas dentro o fuera del pais" 24 . Negrita fuera de texto.

Por su parte, del artículo demandado se puede inferir que el legislador ordinario quiso proteger, con un tratamiento punitivo inferior al estipulado en la trata de personas, el fenómeno peculiar de la explotación de menores que se observa en las calles, el cual a todas luces carece de: i) perspectiva internacional; ii) tráfico de menores; iii) desplazamiento de menores y; iv) una relación accesoria con el crimen organizado.

A continuación, la Sala Plena de la Corporación presenta un cuadro comparativo de los tipos penales bajo análisis, con el fin de ilustrar las diferencias que claramente marcan la conducta demandada con relación al tipo penal de trata de personas: 


\begin{tabular}{|c|c|c|}
\hline $\begin{array}{l}\text { Criterio } \\
\text { diferenciador: }\end{array}$ & $\begin{array}{l}\text { Explotación de menores } \\
\text { (art. 93. L. } 1453 \text { de 2011). }\end{array}$ & $\begin{array}{l}\text { Trata de personas (art. } 188 \text { A y } \\
\text { B, Código Penal) }\end{array}$ \\
\hline Sujeto pasivo & Calificado. & Indeterminado. \\
\hline Verbos rectores & $\begin{array}{l}\text { Utilizar, instrumentalizar, } \\
\text { comercializar o mendigar. }\end{array}$ & $\begin{array}{l}\text { Captar, trasladar, acoger o } \\
\text { recibir. }\end{array}$ \\
\hline $\begin{array}{l}\text { Ingrediente } \\
\text { subjetivo }\end{array}$ & $\begin{array}{l}\text { No presenta ingredientes } \\
\text { especiales en el tipo. }\end{array}$ & Sí: "con fines de explotación". \\
\hline Tipo penal & De resultado. & $\begin{array}{l}\text { De intención: resultado } \\
\text { cortado. }\end{array}$ \\
\hline $\begin{array}{l}\text { Circunstancias } \\
\text { de agravación }\end{array}$ & No existen. & $\begin{array}{l}\text { Si, están contenidas en el } \\
\text { artículo 188-B (Código Penal). }\end{array}$ \\
\hline $\begin{array}{l}\text { Graduación } \\
\text { punitiva }\end{array}$ & 3 a 7 años. & $\begin{array}{l}13 \text { a } 23 \text { años, sin circunstancias } \\
\text { de agravación. }\end{array}$ \\
\hline Bien jurídico & Familia y Libertad. & Libertad y otros. \\
\hline Traslado & $\begin{array}{l}\text { No exige movimiento de } \\
\text { personas. }\end{array}$ & $\begin{array}{l}\text { Sí implica movimiento de } \\
\text { personas, "dentro del territorio } \\
\text { nacional o hacia el exterior". }\end{array}$ \\
\hline $\begin{array}{l}\text { Relación con } \\
\text { el crimen } \\
\text { organizado }\end{array}$ & $\begin{array}{l}\text { No necesariamente cometido } \\
\text { por el crimen organizado. }\end{array}$ & $\begin{array}{l}\text { Cometido por el crimen } \\
\text { organizado. }\end{array}$ \\
\hline
\end{tabular}

Así, en la actividad judicial se pueden diferenciar los tipos penales con un ejemplo práctico: piénsese en un adulto que utiliza menores de edad para que mendiguen todo el día en un semáforo de Bogotá D.C. a cambio de una remuneración, supuesto que correspondería al tipo penal demandado de explotación de menores. Por el contrario, ante un caso en el cual una empresa criminal organizada que opera en varias ciudades, capta y traslada menores de edad de un lugar a otro con fines de explotación, nos encontramos ante el delito de trata de personas.

Ahora bien, también puede ocurrir que en una determinada hipótesis de explotación de la mendicidad ajena con menores, se evidencie cierta semejanza con el tipo penal de trata de personas agravado, en tal caso, los jueces y fiscales correspondientes resolverán el aparente conflicto de leyes de acuerdo con la dogmática penal que ofrece soluciones al respecto bajo los diferentes tipos de concurso de conductas punibles y los principios interpretativos en materia penal, aplicables a la controversia, sin lesionar el principio constitucional de non bis in ídem.

En ese orden de ideas, se disipa la preocupación de la actora acerca de una supuesta desprotección de los derechos de los niños. Todo lo contrario, la consagración de dos tipos penales que protegen de manera diferenciada a los menores de edad permite concluir que el legislador tendió una doble protección para los niños -sujetos de especial protección constitucional-, toda vez que los operadores judiciales tendrán a su alcance mayores 
elementos para encuadrar el caso a la norma verdaderamente aplicable y sancionar autónomamente dos conductas diferentes, las cuales incluso podrán concursar según las circunstancias fácticas. Contrario sensu, la inexequibilidad de la norma sí generaría una alta desprotección en los menores de edad, ya que las conductas que no abarquen la descripción del delito de trata de personas quedarían desprotegidas o, en su defecto, serían sancionadas desproporcionadamente como trata de personas sin serlo.

Por tanto, al comprobarse que las normas objeto de comparación no contienen un patrón común general de comparación sino, por el contrario, presentan notorias diferencias, el Tribunal Constitucional encuentra que no se predica una subsunción o similitud típica necesaria entre ambas conductas punibles para entrar a examinar el fondo del cargo por presunta violación al principio de igualdad.

\subsection{El artículo 93 contenido en la Ley 1453 de 2011, no lesiona el debido proceso por violación al principio de non bis in ídem}

El debido proceso es un principio constitucional de acuerdo con el cual toda persona tiene derecho a unas garantías procesales mínimas, en el marco de las actuaciones judiciales y administrativas. De conformidad con el artículo 29 constitucional y, en relación con el juicio que ahora nos ocupa, implica "no ser juzgado dos veces por el mismo hecho". Tanto para la Corte Constitucional, como para la Sala de Casación Penal de la Corte Suprema de Justicia, se vulnera el non bis in ídem cuando se presenta una triple identidad (objeto, causa y persona) en las dos imputaciones.

Este principio ha variado con el tiempo en el mundo jurídico, en un proceso de extensión continuo, pasó de ser meramente procesal, protegiendo exclusivamente el derecho una vez proferida una sentencia en firme, a un examen material, con independencia de si ello implica la existencia de un proceso judicial y de su ámbito de aplicación, que ha sido tradicionalmente asociado a la infracción jurídico procesal-penal, para convertirse en una garantía constitucional sustancial ${ }^{25}$, de aplicación en todo el ordenamiento jurídico en el cual exista potestad sancionatoria -penal, administrativa, tributaria, disciplinaria-.

En virtud de lo anterior, la violación al principio constitucional de non bis in ídem no solamente procede de manera práctica ante juzgamientos que derivan en sentencias definitivas, amparadas por la cosa juzgada, también puede evidenciarse y prevenirse por el máximo Tribunal Constitucional, por errores de técnica legislativa que conducen en el plano teórico a futuras violaciones constitucionales. Así lo reconocen diversos autores como Del Rey Guanter o Belloch (sic), entre otros, quienes admiten dos vertientes del non bis in ídem, una procesal y otra material, según esta última "cuando el legislador prevé una sanción para un hecho tipificado como infracción, está obligado por el principio de la proporcionalidad a mantener una adecuación entre la gravedad 
de la primera y la segunda, [de ahí que] aplicar una nueva sanción, en el mismo orden punitivo o en otros distintos representaría la ruptura de esa consonancia, una sobrerreacción del ordenamiento Jurídico, que está infligiendo a un sujeto un mal sobre sus bienes mayor o descompensado con respecto al cumplimiento que ha desarrollado del mandato jurídico. En última instancia, el principio non bis in ídem está basado, como en definitiva lo está todo el Derecho, en la idea de justicia, esto es, en la concepción de que a cada uno el ordenamiento Jurídico debe compensarlo o punirlo según su conducta, de forma que iría en contra de la misma una regulación sancionadora que permitiera penalizar al infractor de forma desproporcionada"26.

A su vez, este principio se encuentra reconocido en diversos instrumentos internacionales como en el artículo 14.7 del Pacto Internacional de Derechos Civiles y Políticos, ratificado por la República de Colombia el 29 de octubre de 1969, a cuyo tenor indica, "nadie podrá ser juzgado ni sancionado por un delito por el cual haya sido ya condenado o absuelto por una sentencia firme de acuerdo con la ley y el procedimiento penal de cada país". También en el Convenio de Ginebra sobre el Trato a los Prisioneros de Guerra de 1949, artículo 86, que reza: "El prisionero de guerra no podrá ser castigado más que una sola vez a causa del mismo acto o por la misma acusación".

En el caso concreto, estima la Sala que la norma acusada tampoco vulnera el principio de debido proceso, en parte, por las mismas consideraciones anotadas anteriormente en el examen del cargo por vulneración al principio de igualdad, es decir, el tipo penal demandado, al no ser igual al comparado, no guarda relación con las tres identidades, que permitan configurar vulneración al principio de non bis in ídem en el plano teórico y práctico, esto, por cuanto así pueda existir perfectamente identidad de sujeto activo respecto de quien cometa los diferentes tipos penales, no concurren las demás identidades (objeto y causa) que permiten a la Corporación establecer una vulneración al principio de non bis in ídem, como parte del derecho asociado al debido proceso constitucional.

De acuerdo con los distintos verbos rectores que delimitan la adecuación típica a un caso u otro, no podrá coincidir el objeto de la disposición acusada con el delito de trata de personas, por cuanto por regla general ambos delitos presentan supuestos de hechos divergentes (identidad de objeto). Además, el origen, fundamento o motivación no corresponde para iniciar dos procedimientos penales a la vez (identidad de causa). Por ello, la duplicidad de sanciones o de valoración penal de la disposición acusada con el artículo 188-A del Código Penal, será improbable habida cuenta que las investigaciones y las sanciones tendrán fundamentos normativos y fácticos distintos en dos comportamientos distintos.

Adicionalmente, la problemática planteada en la demanda -más de índole legal y práctica, que de índole constitucional- es resuelta por la misma dogmática penal. En lo concerniente a la función del Tribunal Constitucional de guardar la integridad de la Constitución, interesa dejar suficiente- 
mente claro que no es admisible constitucionalmente por ningún motivo que un operador judicial impute por la misma conducta ambos delitos a la vez, toda vez que quebrantaría la prohibición constitucional de juzgar dos veces el mismo hecho.

En casos de penumbra, el juzgador penal siguiendo el proceso interpretativo penal de adecuación típica, a través del análisis y la ponderación de la situación fáctica con los distintos delitos, debe dilucidar concretamente cuál tipo penal aplicar. Este proceso de adecuación e interpretación de las leyes penales en conflicto se tornará más complejo cuando el hecho humano que el juez deba examinar, se conforme por uno o varios comportamientos de la misma persona que simultáneamente infrinjan los delitos en comparación de explotación de menores y de trata de personas, en cuyo caso deberá tener en consideración el concurso de conductas penales, establecido en el artículo 31 del Código Penal.

También existirán casos concretos en los que se establezca un aparente concurso y se encuadre el caso en un tipo penal específico, así la conducta pareciera subsumirse a la vez en ambos dos tipos penales, el juzgador no podrá estimarlos al mismo tiempo sin violar el principio de non bis in ídem y, por ello, tendrá necesariamente que decidir fundadamente sobre en cuál de ellos imputar la conducta. Para lo anterior, el derecho penal prevé variados criterios de interpretación: especialidad, subsidiariedad, consunción y alternatividad en materia penal, expuestos en la parte considerativa de esta providencia, que contribuyen a resolver en derecho el concurso aparente de leyes penales.

\subsection{Interpretación constitucional de la expresión mendicidad}

No obstante lo anterior, con el objeto de no lesionar la cláusula de Estado Social de Derecho y la garantía de la legalidad de la sanción penal, que orienta el debido proceso constitucional, la Sala Plena de la Corporación pasa a precisar la interpretación de la expresión "mendigue con menores de edad" acusada.

\subsubsection{Interpretación inconstitucional de la mendicidad en la norma demandada}

De conformidad con la demanda, la expresión "mendigue con menores de edad" pretende tipificar la mendicidad con menores sin tener en consideración la realidad del país, en la que muchas familias por situaciones de extrema pobreza, desplazamiento o imposibilidad de encontrar empleo, satisfacen sus necesidades básicas mediante la mendicidad en compañía de sus hijos, sin la intención de explotarlos económicamente.

Para la actora, la locución normativa se presta para una interpretación inadmisible constitucionalmente ya que perfectamente "un padre o madre en las condiciones antes dichas que sea sorprendido ejerciendo la mendicidad propia 
pero en compañía de sus hijos menores de edad, puede ser judicializado por el delito de mendicidad ajena, constituyéndose esto en una forma de criminalizar la pobreza" -folio 15.

En ese sentido, la Sala conviene con la demandante y las intervenciones emanadas de la Defensoría del Pueblo y la Universidad Nacional de Colombia en que una interpretación literal de la expresión demandada "mendigue con menores" conlleva un riesgo objetivo que puede sugerir una criminalización en el ordenamiento penal de la población menos favorecida, aquella que por condiciones económicas y sociales precarias se ve compelida a ejercer la mendicidad autónomamente en compañía de menores.

\subsubsection{Interpretación constitucional de la mendicidad en la norma demandada}

De acuerdo con las consideraciones expuestas en el punto $5^{\circ}$, la Corte considera pertinente reiterar en este asunto que la mendicidad propia, ejercida de manera personal y autónoma por sujetos en estado de debilidad manifiesta, no es sancionable por un Estado Social de Derecho incapaz de proveer a todos sus ciudadanos condiciones mínimas de subsistencia digna. En ese sentido, la interpretación constitucional correcta únicamente admite proscribir la utilización o instrumentalización de menores de edad para la mendicidad, no la mendicidad propiamente dicha, la cual puede ser ejercida autónomamente o en presencia de menores, sin que con ello estén actuando con la intención final de explotar económicamente a estos últimos.

Esto, por cuanto el régimen penal de un Estado Social de Derecho debe valorar al momento de reprochar la mendicidad personal y autónoma, las condiciones de marginalidad, ignorancia o pobreza extrema en el régimen penal ${ }^{27}$. Este Tribunal Constitucional al proteger en múltiples oportunidades "situaciones de vulnerabilidad" 28 , no ha dudado en considerar que la mendicidad propia, soporta una realidad en la cual personas desfavorecidas en la repartición de recursos económicos o marginados de la participación política y ciudadana, se ven obligados a pedir limosna como único medio de subsistencia, sin que por ello coexista una lesión de algún bien jurídico tutelado por la ley a un tercero, ni mucho menos culpabilidad alguna por obrar de esa manera. Lo cual, demuestra que a mayor marginación del sujeto agente de la sociedad, por cuenta de su precaria situación propiciada por diferentes fenómenos externos, menor reproche penal merece en el ordenamiento punitivo.

"La Corte ha sostenido que el derecho penal se enmarca en el principio de minima intervención, según el cual, el ejercicio de la facultad sancionatoria criminal debe operar cuando los demás alternativas de control han fallado. Esta preceptiva significa que el Estado no está obligado a sancionar penalmente todas las conductas antisociales, pero tampoco puede tipificar las que no ofrecen un verdadero riesgo para los intereses de la comunidad o de los individuos; como también ha precisado que la 
decisión de criminalizar un comportamiento humano es la última de las decisiones posibles en el espectro de sanciones que el Estado está en capacidad jurídica de imponer, y entiende que la decisión de sancionar con una pena, que implica en su máxima drasticidad la pérdida de la libertad, es el recurso extremo al que puede acudir al Estado para reprimir un comportamiento que afecta los intereses sociales. En esta medida, la jurisprudencia legitima la descripción típica de las conductas sólo cuando se verifica una necesidad real de protección de los intereses de la comunidad. De alli que el derecho penal sea considerado por la jurisprudencia como la última ratio del derecho sancionatorio" 29 .

Así, proscribir la mendicidad propia o en compañía de menores constituye un atentado contra la dignidad humana, las libertades públicas y los principios penales de última ratio y mínima intervención, por cuanto implicaría inmiscuirse sin justa causa en la supervivencia humana de población vulnerable que busca alimentos, como prerrequisito necesario para gozar efectivamente de todos los derechos fundamentales y satisfacer necesidades de seres humanos.

En esa medida, se condicionará la expresión "o mendigue con menores" acusada en el entendido que el reproche penal recaiga exclusivamente en la utilización de menores para el ejercicio de la mendicidad, no el ejercicio autónomo de la misma en compañía de estos.

\section{Síntesis de la decisión}

En el ejercicio de la acción pública de inconstitucionalidad, la ciudadana María Eugenia Gómez Chiquiza, solicitó la declaratoria de inconstitucionalidad del artículo 93 contenido en la Ley 1453 de 2011, al considerar que la descripción típica genera una total confusión o subsunción penal, violatoria del principio de igualdad (art. 13 C.P.) y de non bis in ídem (art. 29 C.P.), con respecto al delito de trata de personas, consagrado en los artículos 188- A y B del Código Penal. De manera específica, suplicó declarar inexequible la expresión "o mendigue con menores", la cual pretende criminalizar la pobreza.

La Corte Constitucional encuentra que los cargos presentados por la actora no están llamados a prosperar íntegramente. En efecto, en rasgos generales, el tipo penal demandado referente a la explotación de menores, difiere del delito de trata de personas, por cuanto: i) presenta un sujeto pasivo calificado; ii) verbos rectores distintos; iii) no contiene un ingrediente subjetivo en el tipo y; iv) no presenta modalidades de agravación. Adicionalmente, la conducta descrita en la trata de personas siendo un tipo penal de resultado cortado, despliega un traslado de personas, que imposibilita la subsunción en el delito de explotación de menores. Y en caso de existir conflicto entre ambos, la dogmática penal resuelve el asunto bajo la teoría del concurso de conductas punibles y los principios interpretativos de especialidad, subsunción, alternatividad y consunción, los cuales podrán aplicarse por los operadores judiciales en todo momento. 
No obstante, le asiste parcialmente la razón a la demandante respecto de la expresión "mendigue con menores", contenida en la norma acusada, toda vez que literalmente entendida puede representar una forma de criminalizar la pobreza o re victimizar población vulnerable que se encuentra en estado de debilidad manifiesta, en las calles en compañía de su núcleo familiar.

Por tanto, en relación con esta expresión, la Corte al examinar las dos interpretaciones posibles, considera necesario precisar la interpretación constitucional adecuada, con el fin de proteger los derechos fundamentales de esta población desfavorecida, la cual se reitera, no podrá ser perseguida cuando mendigue autónomamente en presencia de menores de edad, sino únicamente cuando utilice o instrumentalice a menores de edad para el ejercicio de la mendicidad.

\section{DECISIÓN}

En mérito de lo expuesto, la Sala Plena de la Corte Constitucional, administrando justicia en nombre del pueblo y por mandato de la Constitución,

\section{RESUELVE:}

Primero.- Declarar EXEQUIBLE el contenido normativo del artículo 93 de la Ley 1453 de 2011, en el entendido que la expresión "mendigue con menores de edad" tipifica exclusivamente la utilización de menores de edad para el ejercicio de la mendicidad y no el ejercicio autónomo de la misma en compañía de estos.

Notifíquese, comuníquese, publíquese, insértese en la Gaceta de la Corte Constitucional, cúmplase y archívese el expediente.

LUIS ERNESTO VARGAS SILVA.

Presidente

Con aclaración de voto

MARÍA VICTORIA CALLE CORREA.

Magistrada

Con aclaración de voto

MAURICIO GONZÁLEZ CUERVO.

Magistrado

Con salvamento de voto

LUIS GUILLERMO GUERRERO PÉREZ.

Magistrado

Con salvamento de voto

GABRIEL EDUARDO MENDOZA MARTELO.

Magistrado 
GLORIA STELLA ORTÍZ DELGADO.

Magistrada

Con salvamento de voto

JORGE IVÁN PALACIO PALACIO.

Magistrado

Con aclaración de voto

JORGE IGNACIO PRETELT CHALJUB.

Magistrado

ALBERTO ROJAS RIOS.

Magistrado

MARTHA VICTORIA SÁCHICA MÉNDEZ.

Secretaria General

\section{Notas}

1 M.P. Eugenio Fernández Carlier. No. de proceso: 39257. 16 de octubre de 2013.

2 Ver Gaceta del Congreso No. 113 de 2001. Exposición de motivos. Representante a la Cámara autora del Proyecto Nelly Moreno Rojas.

3 López, Pinilla. Análisis jurídico penal del delito de trata de personas, artículo 188A del Código Penal Colombiano. Universidad EAFIT, Ministerio del Interior y Organización Internacional de Migraciones, página 19.

4 Sala de Casación Penal de la Corte Suprema de Justicia. M.P. Eugenio Fernández Carlier. No. de proceso: 39257. 16 de octubre de 2013. (F.J. 10.4).

$5 \quad$ C- 1086 de 2008.

6 Reyes, Echandía. Derecho Penal. Ed. Temis, 1994, página 143.

7 Corte Suprema de Justicia. Sala de Casación Penal. 25 de julio de 2007. Aprobado Acta No. 130. M.P. Yesid Ramírez Bastidas.

8 Velásquez, Fernando. Derecho Penal Parte General. Ed. Comlibros. $4^{\mathrm{a}}$ edición, pág. 1011.

9 Posada Maya, Ricardo. Delito continuado y concurso de delitos. Ed: Ibáñez, 2012, pág. 276 y siguientes.

10 Reyes, Op. cit., página 147.

11 Corte Suprema de Justicia, Sala de Casación Penal, sentencias de 9 de marzo de 2006, radicación 23755 y de 10 de mayo de 2001, radicación 
14605, entre otras. La Corte Constitucional lo define como aquel concurso que tiene lugar cuando "una misma conducta parece subsumirse a la vez en varios tipos penales diversos y excluyentes, de tal manera que el juez, no pudiendo aplicarlos coetáneamente sin violar el principio del non bis in ídem, debe resolver concretamente a cuál de ellos se adecua el comportamiento en estudio". (Sentencia C-133/99).

12 El Código Penal colombiano consagra en su artículo $8^{\circ}$ el principio de non bis in ídem, de la siguiente manera: "Prohibición de doble incriminación. A nadie se le podrá imputar más de una vez la misma conducta punible, cualquiera sea la denominación jurídica que se le dé o haya dado, salvo lo establecido en los instrumentos internacionales".

13 Reyes Alvarado, Yesid. El concurso de delitos. Temis: Bogotá, 1990, página 97.

14 Corte Suprema de Justicia, Sala de Casación Penal, sentencia de 15 de junio de 2005, radicación 21629.

15 Ver Corte Suprema de Justicia, Sala de Casación Penal, sentencias 18 de febrero de 2000, radicación 12820, de 10 de mayo de 2001, radicación 14605, y de 9 de marzo de 2006, radicación 23755, entre otras. En similar sentido, ver Corte Constitucional, sentencias C-133/99, C-121/12 y C-1086/08.

16 Corte Suprema de Justicia, Sala de Casación Penal. Proceso No. 37733. M.P. Julio Enrique Socha Salamanca. Aprobado Acta No. 239, 27 de junio de 2012.

17 Velásquez, Op. cit., página 1009.

18 Corte Suprema de Justicia, Sala de Casación Penal, sentencia de 9 de junio de 2004, radicación 22415.

19 Corte Suprema de Justicia, Sala de Casación Penal, sentencia de 8 de mayo de 1996, radicación 10800.

20 Reyes Alvarado, Op. cit., página 119.

21 Exposición de motivos. Gaceta del Congreso No. 113 de 2001.

22 Ibídem.

23 Ponencia para primer debate al Proyecto de Ley 190 de 2001 - Senado. Gaceta del Congreso No. 210 de 2002

24 Exposición de motivos. Gaceta del Congreso No. 113 de 2001.

25 El Tribunal Constitucional Español, (STC 221/1997, de 4 de diciembre, FJ 3, reconoce la violación al non bis in ídem material: "siempre que exista 
identidad fáctica, de ilícito penal reprochado y de sujeto activo de la conducta incriminada, la duplicidad de penas es un resultado constitucionalmente proscrito, y ello con independencia de que el origen de tal indeseado efecto sea de carácter sustantivo o bien se asiente en consideraciones de naturaleza procesal".

26 Ver: DEL REY GUANTER, Potestad sancionadora de la Administración y jurisdicción penal en el orden social, Madrid, 1990, pág. 121 y BENLLOCH PETIT, Guillermo, El principio de non bis in ídem en las relaciones entre el Derecho penal y el Derecho disciplinario, en Revista del Poder Judicial No. 51, pág. 306.

27 El Código Penal establece en su artículo 56 que "el que realice la conducta punible bajo la influencia de profundas situaciones de marginalidad, ignorancia o pobreza extremas, en cuanto hayan influido directamente en la ejecución de la conducta punible y no tengan la entidad suficiente para excluir la responsabilidad, incurrirá en pena no mayor de la mitad del máximo, ni menor de la sexta parte del mínimo de la señalada en la respectiva disposición.

28 Esta Corporación en diversas oportunidades ha amparado a los habitantes de la calle y a los indigentes como grupos poblacionales vulnerables que merecen la protección del Estado. Al respecto ver las sentencias de tutela: T-533/92, T-211/2004, T-166/2007, T-1098/08, $\mathrm{T}-057 / 11$ y $\mathrm{T}-737 / 11$.

\section{Salvamento de voto de la magistrada Gloria Stella Ortiz Delgado a la Sentencia C-464/14}

1.- Con el acostumbrado respeto por la postura mayoritaria de la Sala, la suscrita Magistrada procede a sustentar el salvamento de voto que fue manifestado en la Sala Plena del día 09 de julio de 2014, respecto de la sentencia C-464 de 2014.

2.- En dicha providencia la mayoría decidió declarar la exequibilidad condicionada del artículo 93 de la Ley 1453 de 2011 que tipifica la explotación de menores de edad por no haber constatado violaciones de los principios a la igualdad y de tipicidad. La posición mayoritaria consideró que el tipo penal demandado difiere del delito de trata de personas, de tal suerte que la pena establecida no es desproporcionada a pesar de ser menor en comparación con otros delitos que pueden parecer similares. La sentencia entendió que el delito de explotación de menores y otros semejantes, por ejemplo la trata, son conductas diferentes que, en caso de concurrencia, pueden analizarse bajo la teoría del concurso de hechos punibles y de varios principios interpretativos a fin de aplicar una pena acorde con la gravedad de las situaciones. Por otra parte, para evitar la criminalización de la pobreza -que podría darse en los casos de familias que se dedican a la mendicidad en compañía de los menores- la posición mayoritaria 
consideró que sólo constituye delito la utilización o instrumentalización de los menores de edad para el ejercicio de la mendicidad y no el ejercicio autónomo de la actividad en compañía de éstos.

3.- En mi opinión el artículo 93 de la Ley 1453 de 2011 es inexequible por dos razones ligadas por un elemento común: el carácter especial de la norma demandada dentro de delitos que hacen parte de un género más amplio. En primer lugar, considero que la norma es inconstitucional porque viola los artículos 13 y 44 superiores, en tanto que establece un tipo penal especial, dentro del género de delitos que pretenden castigar las diversas formas de "cosificación" de las personas por parte de individuos o grupos, con menor punibilidad por el sólo hecho de tratarse de la explotación de niños, niñas y adolescentes. El legislador desconoció la especial protección de los niños y de las niñas consagrada en la Constitución al establecer una sanción baja en el delito de explotación de menores de edad con respecto a sanciones determinadas en otras conductas punibles pertenecientes al mismo género. En segundo lugar, considero que la disposición acusada vulnera el principio de legalidad, pues el grado de indeterminación del tipo afectará a los eventuales sujetos activos que sean parte en este tipo de procesos.

4.- Sobre el punto del carácter de este tipo penal como norma especial considero que la explotación de menores de edad corresponde a una especie dentro del género de delitos que sancionan la "utilización" de las personas; de ahí que las supuestas diferencias a las que aludió la mayoría para considerar que se trata de tipos de criminalidad distintos realmente son especificidades sobre el sujeto pasivo de la acción y distinciones nominales sobre los verbos rectores. Efectivamente el delito de explotación de menores de edad no es un delito distinto de otros del mismo género porque sólo agrega la particularización de los sujetos pasivos de la acción. Es posible afirmar también que el mismo nombre del delito indica esa relación entre género y especie con respecto a los sujetos pasivos, en tanto que se trata de una conducta denominada "explotación de menores", que puede ser considerada como parte del género de explotación de seres humanos en general. De hecho el tipo incluye verbos rectores que corresponden a acciones del mismo género de las incluidas en delitos como la trata de personas. La similitud en los verbos rectores puede verse porque aunque se trate de vocablos distintos (en trata captar, trasladar, acoger, recibir y en explotación de menores: utilizar, instrumentalizar, comercializar, mendigar) los verbos se subsumen entre si pues el primer grupo de verbos sólo tiene sentido en función del segundo. Se trata de acciones que forman parte de la cadena de la "cosificación" de personas.

5.- Con base en esta relación entre género y especie, que permite entender la explotación de menores como parte del mismo grupo de delitos al que pertenece, concluyo que la norma es inconstitucional. El legislador excedió su libertad de configuración y desconoció la especial protección constitucional a niños, niñas y adolescentes. En efecto, aunque para tipificar 
conductas penales existe una cláusula general de competencia que dota de una amplia libertad de configuración al legislador, la jurisprudencia de esta Corporación ha advertido en múltiples oportunidades que, no es absoluta porque debe proteger y respetar los derechos y principios constitucionales de los administrados. Así, el legislador debe respetar ciertos límites cuando establece delitos y penas a fin de expedir normas que, entre otros, respeten la dignidad humana, la igualdad y superen un juicio de legitimidad y proporcionalidad, que responderá a distintos niveles de intensidad según la protección constitucional de los bienes y de los sujetos involucrados. ${ }^{1}$

En este caso la norma que tipifica la explotación de menores no supera estos criterios. Efectivamente, en este tipo penal los sujetos pasivos son los niños, niñas y adolescentes, quienes tienen especial protección constitucional (art. 44 C.P.), sin embargo, la pena para quienes los usan como objetos no tiene el mismo rigor que las existentes frente a conductas similares que atentan los derechos de los adultos y adultas. Por eso resulta poco protector ${ }^{2}$ de los niños, niñas y adolescentes que la pena en el caso de explotación de menores de edad sea inferior a la asignada en delitos similares a los adultos y adultas. Por ello, considero que la norma demandada contraría el mandato constitucional según el cual "Serán protegidos contra toda forma de (...) venta, abuso sexual, explotación laboral o económica y trabajos riesgosos" (art. 44 C.P.)

Esta situación configuraría una violación a la dignidad humana (art. 1 C.P.) de los niños, niñas y adolescentes pues si la norma tiene como fin la protección de los menores de edad, una pena inferior hace parecer menos grave su caso que el de otros sujetos pasivos de conductas de "cosificación". Tal diferencia es inconstitucional porque los menores son sujetos de especial protección constitucional. La sanción menor respecto de la impuesta por conductas cometidas a personas adultas también viola el principio de igualdad (art. 13 C.P.), pues explotar menores es menos gravoso en términos punitivos que explotar adultos, lo cual pone a los niños, niñas y adolescentes en una situación diferenciada de desprotección punitiva.

Además de los problemas que tiene la norma al ser irrazonable por violación de la dignidad humana y de la igualdad, tampoco supera un juicio básico de legitimidad y proporcionalidad de la pena. Como la misma Corte lo ha afirmado, ese escrutinio es exigible en materia penal ${ }^{3} y$ en este caso debe considerar que los menores son sujetos de especial protección constitucional y con ello se hace más riguroso el test de análisis de la libertad de configuración del legislador.

Efectivamente, la norma no es legítima porque no satisface el fin de proteger a los niños, niñas y adolescentes a través de la sanción penal. Considero que de la interpretación adecuada de los artículos 188A y 188B del Código Penal, es posible inferir que las conductas de explotación de menores de edad, se encuentran reprochadas y sancionadas penalmente, 
incluso con agravación punitiva cuando se trata de afectar sus derechos. En efecto, los verbos rectores que se encuentran en el tipo penal estudiado, pueden subsumirse en la norma general. Así, los verbos rectores del delito de explotación de menores de edad: utilizar, instrumentalizar, comercializar o mendigar con menores de edad, para efectos de ser explotados (no olvidemos que el nomen del tipo es parte integrante de él), son formas de captar, trasladar, acoger o recibir una persona, con fines de explotación, que son los verbos rectores del delito de trata de personas. Luego, la norma objeto de estudio de la Corte, lejos de proteger los derechos de las niñas, niños y adolescentes, los desatiende.

Tampoco considero que la norma sea proporcional porque no existe razón alguna para que la pena se atenúe en relación con este grupo de sujetos pasivos, que nuevamente reitero, ostenta una protección especial constitucional. Por el contrario incluso podría justificarse una agravación punitiva cuando los sujetos de la explotación son menores de edad. Por tales razones la norma es irrazonable, resulta ilegítima y es desproporcionada al establecer una pena menor para quienes exploten a menores, teniendo en cuenta el estándar de pena en delitos similares. ${ }^{4}$

Finalmente considero que la norma no sólo es inconstitucional sino que envía un mensaje perverso a la sociedad: los niños, niñas y adolescentes pueden ser explotados más fácilmente, puesto que no sólo son más vulnerables sino que la pena por el delito en menor.

6. El segundo argumento por el cual considero que el artículo 93 de la Ley 1453 de 2011 debió ser declarado inexequible es porque resulta violatorio del principio de legalidad, debido a la indeterminación del tipo penal. Como sostuve previamente, la norma analizada es especial dentro de un género de criminalidad más amplio y algunas razones sobre ese tema están directamente relacionadas con mi consideración sobre la violación del principio de legalidad.

En efecto, ya que el nombre del tipo es parte del mismo, a mi juicio la expresión "explotación de menores de edad" no aporta certeza sobre la conducta y menos aún lo hacen los verbos rectores. De hecho éstos parecen subsumirse pues los vocablos "utilizar, instrumentalizar, comercializar o mendigar" no son claros en términos de lo que implica la conducta punible. Por ejemplo, utilizar e instrumentalizar podrían parecer conductas asimilables y en todo caso faltaría determinar en qué consiste cada cual. Piénsese por ejemplo en algunos tipos de trabajo infantil, en la colaboración en ciertas labores domésticas o de supervivencia de las familias, teniendo en cuenta además las especificidades entre áreas rurales, urbanas, y las características de los diferentes niveles socioeconómicos. ¿Bajo qué circunstancias corresponderían a la utilización o instrumentalización de menores? Claramente el tipo penal no aporta elementos para saber cuándo estamos en presencia de la conducta punible y cuándo no. 
Sobre el deber de claridad en la tipificación de los delitos la jurisprudencia de la Corte ha sido contundente, como quiera que "el legislador está obligado a definir la conducta punible de manera clara, precisa e inequívoca" ${ }^{\prime}$. Por eso el ordenamiento proscribe puniciones imprecisas ${ }^{6}$ a fin de respetar plenamente el principio de estricta legalidad que tiene como objetivo evitar que la definición de conductas punibles sea hecha por los jueces o por la administración ante la necesidad de precisar vaguedades establecidas en la ley. ${ }^{7}$

Este tipo penal no cumple con una descripción clara, precisa e inequívoca que permita a los ciudadanos saber qué comportamientos están prohibidos o permitidos (Art. 6 C.P.). Tal es la vaguedad de la norma que el mismo análisis hecho por la mayoría de la Corte tuvo que dedicar una parte significativa al esclarecimiento de las diferencias entre el delito de explotación de menores y otros delitos similares, con lo cual la norma revela varios equívocos. El artículo 93 de la Ley 1453 de 2011 no es concreto, preciso ni específico con lo cual no supera el estándar mínimo que debe tener una norma penal para que la población entienda con claridad y de manera previa, qué conductas pueden tener como consecuencia una sanción penal. Esta indefinición da a los jueces un margen de discreción intolerable en nuestro ordenamiento constitucional con lo cual los derechos de los eventuales sujetos activos de este delito pueden ser violados por la propia administración de justicia.

7.- Sumado a la ambigüedad del tipo penal objeto de estudio, la Corte Constitucional introdujo un condicionamiento aún más confuso, pues se despenalizó "el ejercicio autónomo" de la mendicidad con menores de edad, en compañía de los padres. Ahora, aunque comparto plenamente la idea de que no es posible sancionar penalmente el ejercicio de la mendicidad como un instrumento de subsistencia humana, lo cierto es que el condicionamiento me deja la duda de si, ¿es penalmente reprochable la utilización de menores de edad por parte de sus padres, cuando tiene fines de explotación económica? La lectura literal del condicionamiento parecería favorecer una respuesta afirmativa, lo cual es realmente grave para la defensa de los derechos de los niños, niñas y adolescentes. Sin duda, por regla general, a la Corte Constitucional no le corresponde configurar normativamente las conductas humanas que constituyen delitos ni describir los tipos penales.

8.- En consecuencia, no existen, para la suscrita Magistrada, razones de peso que permitieran mantener en el ordenamiento el artículo 93 estudiado, pues se trata de una norma que vulnera los artículos $1^{\circ}, 13,28$ y 44 de la Constitución, al establecer: i) una pena desproporcionadamente menor para la explotación de menores de edad, en detrimento del deber de protección especial que el Estado debe brindar a las niñas, niños y adolescentes y, ii) un tipo penal indeterminado.

Fecha ut supra, 


\section{Notas}

1 La sentencia C-084 de 2013 se refirió al tema y dijo que la potestad de configuración normativa en materia penal incluye la posibilidad de hacer regulaciones con respeto la integridad de los valores, principios y derechos establecidos por la Constitución.

2 La jurisprudencia ha reiterado que los tipos penales son mecanismos extremos de protección de derechos, ver la sentencia C-587 de 1992.

3 Por ejemplo la sentencia C-070 de 1996 explicó la posibilidad de inconstitucionalidad de una pena por exceso y la sentencia C-125 de 2003 aludió tanto al exceso como a la protección deficiente. En ambos casos la Corte ha enfatizado que sólo en el evento de desproporcionalidad e irrazonabilidad manifiestas podría este tribunal retirar del ordenamiento la disposición que fija una sanción penal. Del mismo modo, en esta última sentencia la Corte ha insistido en que existen límites constitucionales en el ejercicio de la política criminal.

4 Una situación análoga ya fue estudiada por la Corte Constitucional en la sentencia C-285 de 1997 en la cual concluyó que una norma que establecía una pena menor en el caso de violencia sexual entre cónyuges con respecto a delitos de violencia sexual cometidos por sujetos pasivos indeterminados, era inexequible por razones similares a las citadas hasta ahora en este salvamento de voto: irrazonabilidad, violación del derecho a la igualdad y violación de la dignidad humana.

5 La reconstrucción de esta línea jurisprudencial puede verse en la sentencia C-084 de 2013.

6 Ver la sentencia C-205 de 2003.

7 Ver la sentencia C-084 de 2013.

\section{Comentario}

\section{La disposición demandada y el Derecho penal complementario.}

La primera precisión que debe hacerse, de cara a pronunciarse sobre el interesante debate que propicia el tenor literal del artículo 93 de la ley 1453 de 24 de junio de 2011 (por medio de la cual se reforman el Código Penal, el Código de Procedimiento Penal, el Código de Infancia y Adolescencia, las reglas sobre extinción de dominio y se dictan otras disposiciones en materia de seguridad) y el pronunciamiento de constitucionalidad del cual ha sido objeto por medio de la Sentencia transcrita, que consagra dos normas penales completas con sus respectivos supuestos de hecho (tipos penales) y consecuencias jurídicas, es que el mismo no forma parte del Derecho penal fundamental sino del Derecho penal complementario (para algunos 
llamado como accesorio, voz que se emplea como equivalente a la locución alemana Nebenstrafrecht: Roxin, I, 1997, p. 44; Roxin, I, 2006, p. 4). Esto es, esa normativa no pertenece al conjunto de normas penales organizadas en un solo cuerpo de ley, esto es codificadas, sistematizadas y dictadas por un único legislador (un verdadero sistema cerrado) -el primero de los citadossino que, por el contrario, hace parte de aquellas leyes penales distintas del Código Penal, sean de vigencia anterior o posterior (como aquí), que consagran tipos penales y sus respectivas consecuencias jurídicas o bien se refieren a principios generales en materia penal de diversa índole -el segundo de los nombrados- (Velásquez, 2009, I, pp. 237-244; Velásquez, 2014, pp. 111-118).

La anterior precisión es importante porque uno de los temas más álgidos del debate es el atinente a si esas dos normas penales son o no reiteración de las contenidas en el Código Penal, en materia de trata de personas (art. $188 \mathrm{~A}$ y 188B), asunto en el cual es necesario sentar una postura clara para evitar equívocos posteriores. Por lo demás, se debe tener en cuenta que todos y cada uno de los principios que rigen el Derecho penal fundamental se aplican al Derecho penal complementario.

\section{El olvido de las teorías de la norma penal y del tipo penal.}

En la demanda, la providencia en examen y el salvamento transcrito, se evidencian falencias metodológicas que tocan con los rudimentos de la ciencia del Derecho penal, las cuales empiezan cuando la persona que confeccionó la demanda (Cfr. Transcripciones en III), la Corte (Cfr. este texto: "una vez analizados los verbos rectores de ambos tipos penales, el tipo penal demandado se encuentra subsumido totalmente por el tipo penal anterior contenido en el Código Penal colombiano" y los intervinientes (Cfr. IV), llaman tipo penal a todo el contenido normativo del artículo 93 de la Ley 1453 de 2011; en otras palabras, como ya es usual en el antitécnico debate nacional en esta materia, se confunde la expresión artículo del Código Penal con la de tipo penal (para los alemanes supuesto de hecho o Tatbestand) (Velásquez, I, 2009, p. 296); incluso, se pretende identificar esa inexistente noción de tipo con la de supuesto de hecho, como se infiere de lo afirmado en el aparte III. 2, al referirse al artículo 188A del Código Penal: "Este supuesto de hecho conlleva a una presunta vulneración del principio de igualdad" (cursivas propias).

Al respecto, debe recordarse que las construcciones dogmáticas más difundidas suelen entender esta locución de diversas maneras: en sentido sistemático, como un instrumento legal, lógicamente necesario y de naturaleza predominantemente descriptiva, que tiene por función la individualización de conductas humanas (Zaffaroni, III, 1981, p. 167). Además, fuera de esta noción estricta, se concibe también como tipo de injusto para referirse al conjunto de características que fundamentan la antijuridicidad de una acción; de tipo de culpabilidad, para comprender 
las características que cimientan la culpabilidad del autor; de tipo de delito, para señalar tanto las características pertenecientes al tipo de injusto como al tipo de culpabilidad; y, para concluir, de tipo en la teoría general del derecho, o conjunto de presupuestos de los que depende la producción de una consecuencia jurídica, noción que aplicada al Derecho penal comprende tanto los tipos de injusto y de culpabilidad como de las llamadas condiciones objetivas de punibilidad.

Esto, para no mencionar conceptos tan problemáticos como el de tipo de garantía, comprensivo de todos los elementos que participan de la función de garantía de la ley penal (principio de legalidad), o tan especializados como el de tipo total de injusto (que engloba tanto de las características fundamentadoras de la antijuridicidad como de las que la excluyen: causales de justificación), o el de tipo de permisión (equivalente a las causales de justificación), entre otros (Véase, Jakobs, 1997, pp. 191 y 192; Jescheck/ Weigend, 2002, pp. 264; Schönke/Schröder/Lenckner/Eisele, 2014, pp. 155156; Velásquez, I, 2009, pp. 640-642).

Así las cosas, mucho ayudaría al debate en estas materias que tanto los accionantes e intervinientes (muchos de ellos mal reclutados o movidos por un innecesario y dañino protagonismo) como la propia Corte Constitucional respetaran, en toda su dimensión, el debate académico del cual se dice partir; en otras palabras, no se puede pretender hacer dogmática del Derecho penal irrespetando los esfuerzos que los constructores de esta disciplina han hecho durante décadas de decantados trabajos y una productiva construcción intelectual. Por eso, aquí debe empezarse por reprochar el indebido manejo que se hace de las categorías propias de la teoría de la norma penal y de la teoría de la tipicidad.

\section{Sobre los alcances sustantivos del principio del non bis in idem.}

Tampoco es del todo afortunada la utilización del axioma citado cuando la demanda afirma la existencia de una 'confusión típica' entre los contenidos normativos de los artículos 188A y 188B del C. P. y la norma impugnada (véase la transcripción que aparece en III, 3 y la referencia de VI, 2 primer párrafo); en otras palabras, se entiende que como los tipos penales contenidos en esos artículos son en apariencia coincidentes se desconoce ese principio procesal que forma parte ineludible del debido proceso legal, a la vez expresión de las prerrogativas procesales que emanan del principio de legalidad como límite formal por excelencia al ejercicio de la potestad punitiva del Estado. Se olvida, pues, que con este axioma se reputa que el juicio sobre la litis es inmutable, intocable, definitivo y no puede ser modificado por el juez, una vez que la decisión de fondo se encuentra en firme (Velásquez, I, 2009, pp. 214-216; Corte Constitucional: sentencias C-244, 1996, mayo 30; T-652, 1996, noviembre 27; T-162, 1998, abril 30; T-512, 1999, julio 15; T-537, 2002, julio 15; C-121, 2012, febrero 22 entre otras) y se le terminan dando unos inusuales alcances sustantivos (que de todos modos 
los tiene) que desplazan, incluso, toda la teoría de la tipicidad penal y, dentro de ella y como problemática suya, la teoría de la unidad y pluralidad de acciones típicas.

Desde luego, nadie discute que es aceptable darle unos alcances sustantivos al axioma en mención (por ejemplo, Mañalich, 2011, p. 142; Orts \& González, 2014, p. 140, con citas de la jurisprudencia española), pero todo ello de forma limitada como lo hace la providencia en comento cuando lo liga con el principio de proporcionalidad ( $\mathrm{y}$, por supuesto, habría que hacerlo con el del acto); incluso la Sentencia va más allá hasta casi convertirlo en uno de los pilares de la técnica legislativa: "la violación al principio constitucional de non bis in ídem no solamente procede de manera práctica ante juzgamientos que derivan en sentencias definitivas, amparadas por la cosa juzgada, también puede evidenciarse y prevenirse por el máximo Tribunal Constitucional, por errores de técnica legislativa que conducen en el plano teórico a futuras violaciones constitucionales" (Ver, VI, 6.2).

\section{El entendimiento del principio de taxatividad como componente del debido proceso.}

De igual forma, debe cuestionarse la forma como la demanda involucra el llamado principio de taxatividad o de determinación -que para nada tiene que ver con las prerrogativas procesales que emanan del principio de legalidad, no así con las de corte sustantivo de las cuales sí dimana-con el postulado del debido proceso legal (véase la afirmación que aparece en III, 5: «la actora indica que la expresión "o mendigue con menores de edad" contenida en el artículo demandado vulnera el debido proceso al pretender tipificar la mendicidad con menores de edad»); sobre ello, se han ocupado de manera profusa tanto la doctrina nacional (Velásquez, I, 2009, pp. 189203) como la extranjera (Ferrajoli, 2006, p. 376) [que lo llama como principio de legalidad estricta] y la misma jurisprudencia (Véase. Sentencias C-205, 2003, marzo 11; C-238, 2005, marzo 15; C-996, 2000, agosto 2).

Debe, pues, quedar claro que el postulado en mención es una de las consecuencias del principio nulla poena sine lege en el plano sustantivo; por eso se dice que no hay delito, no hay pena, no hay medida de seguridad sin una ley cierta: nullum crimen, nulla poena, nulla mensura sine lege certa. Esto significa que tanto las conductas mandadas o prohibidas por la ley penal (esto es, el supuesto de hecho, precepto o tipo penal) como las consecuencias que consagra el ordenamiento para ser impuestas a quienes trasgredan sus disposiciones (consecuencias jurídicas, sanciones), sea que se trate de penas o de medidas de seguridad, deben estar claramente consignadas en ella (Velásquez, 2009, I, pp. 189-203). Para nada, pues, este axioma es expresión del debido proceso legal porque ello supondría trastrocar el programa penal de la Constitución (Véase, Berdugo et al., 2010, p. 43 y ss.). 


\section{La exposición sobre la teoría de la unidad y pluralidad de acciones típicas.}

También discurre la providencia, de forma amplia, sobre la susodicha construcción llamada así por la doctrina nacional en la que se apoya (Velásquez, 2009, II, p. 1147) y lo hace de manera compartible; el problema radica, sin embargo, en que ese tribunal no tuvo en cuenta que los diversos autores citados hacen sus elaboraciones a la luz de concepciones harto diversas y que lo entendido por uno $u$ otro instituto en esta materia, va a depender del punto de partida asumido (Véanse. Mir \& Gómez, 2011, pp. 647-668; Orts \& González, 2014, pp. 141-152; Roxin, II, 2014, pp. 939-1036). En otras palabras, no se pueden unificar las construcciones de Velásquez, Reyes E., Reyes A., Posada M., etc. porque cada uno de ellos, tiene un entendimiento propio del asunto.

Dicho de otra forma: de cara a enfrentar de mejor manera la discusión lo primero que se debe es precisar el concepto de acción (en sentido amplio: acción y omisión) para poder, a partir de allí, emprender la alzadura teórica respectiva; esto, aunque no se crea, es fundamental porque de ello dependen los alcances que se le den a las arquitecturas del concurso material de delitos, el concurso ideal, el concurso aparente, el delito continuado y los llamados delitos masa.

\section{Las figuras cuestionadas no son especies de las de trata de personas.}

El art. 188A (en armonía con el 188B), no prevé propiamente la explotación de las personas sino su captación con esa finalidad; son tipos penales con elementos subjetivos del tipo distintos al dolo y no se requiere que se realice ese plus adicional, representado por conductas como la explotación de menores que por eso son punidas en forma independiente; así las cosas, lo que se castiga es la conducta del que capte, traslade, acoja o reciba a cualquier persona (adulto o menor).

Los actos de explotación encajan en otras descripciones típicas (por ejemplo proxenetismo, turismo sexual, secuestro, desaparición forzada, etc.) y, si ello no sucede, debieran estar penados de forma independiente. El legislador, si se quiere y con base en las directrices de los convenios internacionales sobre el asunto, adelanta las barreras de punición para proteger el bien jurídico en los estadios más iniciales cuando empiezan a manifestarse los actos preparatorios de la explotación (la consecución de los seres humanos que se van a aprovechar).

Es más, esas complejas figuras de los artículos antedichos por sí solas pueden también comportar la realización de otras conductas típicas; dicho de otra manera, para aprontar las personas es necesario privarlas ilegalmente de su libertad (secuestrarlas), cambiarles su identidad (falsificar documentos), drogarlas para el transporte con el consecutivo daño en el cuerpo o en la salud (lesiones personales, por ejemplo), etc. 
En fin, el delito de explotación de menores previsto en el art. 93 de la Ley 1453 de 2011 va más allá de las fases previas acabadas de señalar y castiga los actos de aprovechamiento propiamente; por eso se pune al que utilice, instrumentalice, comercialice o mendigue con menores de edad. Y ello, como es obvio, supone la actividad previa de captar al sujeto pasivo de la acción pues no se puede explotar al que no se tiene en su poder para esos fines. Esto último, por supuesto, no lo advirtió la demanda de inconstitucionalidad -y con ella el salvamento de voto- que confundió los dos momentos y las dos fases de los comportamientos; no es, pues, lo mismo realizar la trata de la persona que explotarla, sea menor o adulta. Tiene, pues, razón la providencia cuando asevera que:

“(...) los delitos en comparación de explotación de menores, contenido en el artículo 93 de la Ley 1453 de 2011 y el delito de trata de personas estipulado (sic) en el artículo 188-A del Código Penal no tienen identidad típica por cuanto se diferencian en cuatro puntos cardinales" (Ver. VI, 3.3.).

En síntesis: se trata de grupos de figuras muy distintas así ambas estén en la cadena delictiva que se inicia con la trata de personas en sentido estricto y conducen hasta su explotación. Por ello, pues, las diversas precisiones que hace la providencia de cara a distinguir los diversos tipos de conductas involucrados en el debate son perfectamente compatibles y no ameritan reproche alguno.

\section{El bien jurídico tutelado por la norma demandada.}

Pese a que la Sentencia señala como bienes jurídicos protegidos por el artículo 93 de la Ley 1453 de 2011 (Ley de seguridad ciudadana) los concernientes a la familia y la libertad, debe decirse que ello no necesariamente es así. En efecto, téngase en cuenta que esa disposición aparece inserta en el Título IV de la Ley que se denomina Medidas para garantizar la seguridad ciudadana relacionadas con el Código de la Infancia y la Adolescencia, esto es, el legislador entendió que el comportamiento de explotar a los menores de edad pone en peligro ese inasible bien jurídico, de carácter colectivo y abstracto, que se llama seguridad ciudadana, un concepto que "se ha convertido en una mercancía que centra los debates políticos, a la vez que también se recurre como instrumento electoral a las promesas de mayor rigor y severidad penal" (Rivera y Monclús 2005, p. 19). Por ello, esa previsión legislativa es expresión del denominado Derecho penal de la seguridad ciudadana (Díez, 2007, p. 69); este último, un diseño propalado por las potencias para conjurar los brotes de delincuencia que asolan a la comunidad planetaria actual (Garland, 2005, pp. 9 y ss., 31 y ss., 179 y ss.), una de cuyas más crudas expresiones es el modelo de la Tolerancia cero puesto en ejecución, en los años noventa del siglo pasado, por R. Giuliani, el exalcalde de Nueva York (sobre ello, De Giorgi, 2005, p. 37 y ss., 153 y ss.; Wacquant, 2000, p. 32 y ss.) y diseminado a lo largo y ancho del continente en la primera década de este siglo. De ahí, pues, el nombre dado por el legislador vernáculo a la citada legislación, que 
reproduce las mismas denominaciones y hasta los contenidos que se aprecian en reformas similares operadas en otros países y no sólo en el subcontinente latinoamericano (Velásquez, 2013, p. 297).

En fin, a la hora de precisar el bien jurídico, no se puede echar de menos que esa normativa -cosa que ni por asomo se le ocurrió decirlo a la Corte Constitucional aquí- aparece en el marco de un Derecho penal expansionista, no sólo en contravía de los dictados de la Constitución y de un Derecho penal liberal sino en el contexto de una marcada fragmentación social y con una notoria desigualdad económica, por lo cual debe entenderse como una manifestación más de un Derecho penal de enemigo, de ahí que no sea descabellado pensar-como lo propone la demanda y lo estima la Corte e incluso el Salvamento de voto que se estudia- que su intención era criminalizar de forma abierta la mendicidad, incluso la realizada por los parientes del menor, como se infiere del supuesto de hecho de la norma penal completa que aparece en el inciso $2^{\circ}$ cuando reza: "La pena se aumentará a la mitad cuando el actor sea un pariente hasta el cuarto grado de consanguinidad, segundo de afinidad o primero civil", esto es, se castiga con pena privativa de libertad que fluctúa entre cuatro años y medio y diez años y medio a quien, como sujeto activo pariente de la víctima, "utilice, instrumentalice, comercialice o mendigue con menores de edad directamente o a través de terceros". El propósito, pues, era claro: se trataba de castigar la mendicidad en ese preciso ámbito, como adujo la demanda.

\section{Un indebido pronunciamiento de constitucionalidad condicionada.}

En el contexto indicado, pues, una ley que criminalice la mendicidad debe entenderse como contraria a la Carta Fundamental (así, Corte Constitucional, sentencias C-1068, 2002, diciembre 3; C- 040, 2006, febrero 1; C-365, 2012, mayo 16) y el análisis que aparece en VI, 5 y VI, 6.3.2.), no solo por ser expresión de un Derecho penal de la seguridad ciudadana, expansionista, que se lleva de calle toda la organización social diseñada por el constituyente de 1991 (preámbulo, parte dogmática de la Constitución Política) sino porque no pone en peligro los demás bienes jurídicos (la familia y la libertad) que se dicen proteger; es más, semejante normatividad es producto de un Derecho penal de autor no de uno de acto que es el plasmado en la Constitución, porque persigue a las personas no por lo que hacen sino por lo que son: por ejemplo, mendigos.

En estas condiciones, resulta desafortunado el pronunciamiento de la Corte cuando -al tomar el lugar del legislador y en contravía del principio de legalidad y, por ende, de todo el andamiaje constitucional amén de sus propios precedentes- decide declarar ajustado a la ley de leyes el aparte demandado, pero condicionado a una interpretación que está llamada a generar muchos equívocos. Lo procedente era, pues, declarar inexequible ese aparte del tenor literal cuestionado por la demandante. 
Este tipo de pronunciamientos, recuérdese, han sido rechazados por la propia Corte como se deduce de la sentencia C-238 de 2005 (que reitera lo dicho en la sentencia C-843 de 1999), lo siguiente:

\begin{abstract}
"En este orden de ideas, ha señalado también que en caso de ambigüedad de la norma penal lo procedente no es que la Corte dicte una sentencia interpretativa, para precisar la descripción de la conducta o el señalamiento de la pena de conformidad con la Constitución, pues dicha sentencia sería contraria al principio de legalidad en sentido amplio, por tratarse de una competencia exclusiva del legislador, y en cambio debe declarar su inexequibilidad.
\end{abstract}

Es más, recuérdese lo expresado en la sentencia C-996 de 2000:

[A]l funcionario judicial no le corresponde la función de crear tipos penales, en razón de que esta labor conforme quedó antes expresado, corresponde al legislador, según las voces del numeral 2 e inciso 3 del artículo 150 de la Constitución. Por eso resulta importante resaltar que la actividad del funcionario judicial habrá de ser complementaria en la medida que debe constatar si los hechos legalmente establecidos y probados dentro del proceso penal, se adecuan a los elementos que se establecen en los tipos penales".

En síntesis: la Corte debió declarar inconstitucional el aparte demandado y no acudir al odioso mecanismo del cual se ha valido porque, con ello, suplanta al legislador en su tarea y pisotea la Ley de Leyes.

\title{
Las conclusiones del Salvamento de voto.
}

Si se observa esta pieza procesal (la única conocida hasta la fecha, pues nada se sabe los restantes dos salvamentos y de las tres aclaraciones anunciadas: en Colombia, de forma ilegal, también en esta materia se anuncian los fallos y sus adendas y se dan a conocer cuando a bien se tiene) se encuentra que la misma proclama la inexequibilidad de la norma demandada por dos razones: una porque desconoce los artículos 13 y 44 de la Carta fundamental, pues "establece un tipo penal especial, dentro del género de delitos que pretenden castigar las diversas formas de "cosificación" de las personas por parte de individuos o grupos, con menor punibilidad por el sólo hecho de tratarse de la explotación de niños, niñas y adolescentes"; y la otra, porque "la disposición acusada vulnera el principio de legalidad, pues el grado de indeterminación del tipo afectará a los eventuales sujetos activos que sean parte en este tipo de procesos".

Sin duda, al demostrarse que no existe esa relación de género a especie entre los textos normativos debatidos, se derrumba toda la construcción académica que en torno a ello se hace, con lo cual el primer argumento se esfuma pues parte de premisas que no son ciertas; en cuando al segundo razonamiento, y es de suyo evidente que los dos tipos penales contenidos en el artículo 93 tienen visos de indeterminación en cuanto no respetan el postulado de taxatividad, parecería viable plantear la inconstitucionalidad 
de los mismos. Sin embargo, si como dice la Corte "la presente acción de inconstitucionalidad se circunscribe a cargos por presunta vulneración al principio de igualdad y al debido proceso" (ver, III, cuarto párrafo), todo parece indicar que en ese escenario no cabía pensar en semejante declaratoria de inconstitucionalidad (la que atiende a la totalidad del texto) no así la correspondiente al aparte (que fue pedida de forma expresa); era, entonces, indispensable que la demanda hubiera enfocado sus cuestionamientos a la vulneración del principio de legalidad estricta.

La mala técnica observada por el impugnante ha dado al traste con la posibilidad de entablar un mejor debate sobre el asunto, máxime si se tiene en cuenta que la jurisprudencia ha sido clara al señalar que los supuestos de hecho y las consecuencias jurídicas consignadas en las normas penales no pueden ser indeterminadas, imprecisas, gaseosas, etc. (sentencias C-742 de 26 de septiembre de 2012; C-365 de 2012).

En efecto: en virtud de los principios de legalidad y tipicidad el legislador se encuentra obligado a establecer claramente en qué circunstancias una conducta resulta punible y ello con el fin de que los destinatarios de la norma sepan a ciencia cierta cuándo responden por las conductas prohibidas por la ley. No puede dejarse al juez, en virtud de la imprecisión o vaguedad del texto respectivo, la posibilidad de remplazar la expresión del legislador, pues ello pondría en tela de juicio el principio de separación de las ramas del poder público, postulado esencial del Estado de Derecho(C-843, 1999, octubre 27).

\section{Conclusiones.}

- Con independencia de que se compartan o no los planteos contenidos en la sentencia, no deja de ser saludable y reconfortante que -en medio de la apatía reinante por estos asuntos- providencias como esta acudan a las construcciones teóricas de la Dogmática penal para tratar de apuntalar las decisiones.

No obstante, es necesario reclamar un mejor manejo conceptual de los postulados propios de la Dogmática jurídico penal a la hora de emprender estos debates para que los mismos sean más productivos y se logre, de verdad, que ese organismo vele por la guarda e integridad de la Constitución.

Por ello, pese a que son compartibles los desarrollos que hace la providencia en materia de unidad y pluralidad de acciones, no debe perderse de vista que el debate por ella recogido responde a muy disímiles enfoques, lo que está llamado a generar equívocos. Nada aporta, pues, semejante eclecticismo doctrinario a la construcción de un sistema del Derecho penal desde la interpretación de la Constitución, como debiera hacerse.

$\mathrm{Si}$, con base en los edificios propios de la Dogmática jurídico penal, se hace un análisis riguroso de los contenidos normativos de los artículos 93 de la Ley 1453 de 2011 y 188A y 188B, se puede concluir con toda certeza que los dos 
grupos de las diversas descripciones típicas regulan conductas completamente distintas, así sea verdad que ellas formen parte la cadena de comportamientos que implica la realización de los delitos de trata de personas.

No hay, pues, una relación de género a especie entre las últimas previsiones típicas y las primeras, aunque sí se evidencia que las primeras prevén conductas que implican un desarrollo ulterior de las últimas.

Si lo anterior es así, no puede hablarse de un trato desigualitario a la hora de hacer las comparaciones entre las consecuencias jurídico-penales imponibles en los diversos casos, como lo reclama la demanda. Es más, si ello fuera cierto sería necesario extender ese estudio a todas aquellas disposiciones que pueden llegar a ser vulneradas por las redes que trafican con personas $\mathrm{y}$, además, las utilizan o instrumentalizan, explotándolas.

Es posible pensar en los alcances sustantivos del principio del non bis in idem, pero ello no puede llevar a suplantar las construcciones de la Parte general de Derecho penal sino que, por el contrario, esos desarrollos deben estar ligados con ella; en ello, pues, acierta la providencia.

El proveído ha debido declarar la inexequibilidad del aparte demandado y no proceder, como lo hizo, a acudir a la figura de la constitucionalidad condicionada en el entendido de que se debe plegar a una interpretación determinada que, por lo demás y como lo asegura el Salvamento de voto, no deja de ofrecer graves dificultades. Los jueces constitucionales, pues, no deben ser legisladores.

El único Salvamento de voto que pudo ser examinado incurre, en su primer punto de partida (cuando habla de una relación de género a especie entre las figuras en cuestión), en el mismo yerro que el accionante; por ello, su planteamiento es equivocado y sus conclusiones deben ser desechadas.

En relación con su afirmación encaminada a pregonar la inexequibilidad de todo el texto de la norma demanda, debe decirse que se trata de una postura compartible cuando se parte de las elaboraciones propias del principio de taxatividad o de determinación, el problema es que hasta donde se entienden los alcances de la providencia semejante declaratoria desconocería los límites que tiene el juez constitucional en cuanto debe circunscribirse al objeto de la demanda de inconstitucionalidad (véase artículo 241 de la Constitución y normas concordantes).

\section{Referencias}

Berdugo, I. et al. (2010). Curso de Derecho penal. Parte general. (2 ${ }^{\mathrm{a}}$ ed.) Barcelona: Ediciones Experiencia, S. L.

De Giorgi, A. (2005). Tolerancia Cero. Estrategias y prácticas de la sociedad de control (Prefacio de Toni Negri, Presentación y traducción de Iñaki Rivera y Marta Monclús). Barcelona: Virus Editorial. 
Díez, J. L. (2007). La Política Criminal en la encrucijada, Montevideo/Buenos Aires: B de F.

Garland, D. (2005) La cultura del control. Crimen y orden social en la sociedad contemporánea (trad. de Máximo Sozzo). Barcelona: Gedisa Editorial.

Ferrajoli, L. (2006) Derecho y razón. (Tr. P. Andrés Ibáñez et al.). Madrid: Trotta.

Jakobs, G. (1997). Derecho Penal, Parte General. Fundamentos y teoría de la imputación. ( $2^{\mathrm{a}}$ ed.). (Tr. Joaquín Cuello Contreras y José Luis Serrano González de Murillo). Madrid: Marcial Pons Ediciones Jurídicas.

Jescheck, H. H. y Weigend, T. (1996). Lehrbuch des Strafrechts (5a ed.). Berlin: Duncker \& Humblot.

Jescheck, H. H. y Weigend, T. (2002). Tratado de derecho penal, parte general, (traducción española y notas de M. Olmedo Cardenete). Granada: Editorial Comares.

Mañalich, J. P. (2011). El principio ne bis in idem en el Derecho penal chileno. En: REJ - Revista de Estudios de la Justicia, (15), 139-169.

Mir, S. y Gómez, V. (2011): Derecho penal, Parte General (9ª ed.) Barcelona: Editorial Reppertor.

Roxin, C. (1997). Derecho penal, Parte general, t. I (trad. española de la $2^{a}$ ed. alemana y notas a cargo de Diego Manuel Luzón Peña, Miguel Díaz y García Conlledo y Javier de Vicente Remesal). Madrid: Civitas.

Roxin, C. (2003). Strafrecht, Allgemeiner Teil, t. II, Besondere Erscheinungsformen der Straftat (1 $1^{a}$ ed.). München: C. H. Beck.

Roxin, C. (2006). Strafrecht, Allgemeiner Teil. t. I (4a ed.). Grundlagen, Der Aufbau der Verbrechenslehre. München: C. H. Beck.

Roxin, C. (2014). Derecho penal, Parte general, t. II (trad. española de la $1^{\text {a }}$ ed. alemana y notas a cargo de Diego Manuel Luzón Peña (director) et al.) Madrid: Civitas-Thomson Reuters.

Schönke, A. y Schröder, H. (2014): Strafgesetzbuch. Kommentar (29a ed.). München: Verlag C. H. Beck.

Sentencia C-244 (1996, mayo 30). Demanda de inconstitucionalidad. M. P. Carlos Gaviria Díaz. Corte Constitucional.

Sentencia C-843 (1999, octubre 27). Demanda de inconstitucionalidad M. P. Corte Constitucional. M. P. Alejandro Martínez Caballero. Corte Constitucional.

Sentencia C-996 (2000, agosto 2). Demanda de inconstitucionalidad. M. P. Antonio Barrera Carbonell. Corte Constitucional. 
Sentencia C-1068 (2002, diciembre 3) Demanda de inconstitucionalidad. M. P. Jaime Araujo Rentería. Corte Constitucional.

Sentencia C-205 (2003, marzo 11). Demanda de inconstitucionalidad. M. P. Clara Inés Vargas Hernández. Corte Constitucional.

Sentencia C-238 (2005, marzo 15). Demanda de inconstitucionalidad M. P. Jaime Araujo Rentería. Corte Constitucional.

Sentencia C- 040 (2006, febrero 1). Demanda de inconstitucionalidad. M. P. Jaime Araujo Rentería. Corte Constitucional.

Sentencia C-121 (2012, febrero 22). Demanda de inconstitucionalidad. M. P. Luis Ernesto Vargas Silva. Corte Constitucional.

Sentencia C-365 (2012, mayo 16). Demanda de inconstitucionalidad. M. P. Jorge Ignacio Pretelt Chaljub. Corte Constitucional.

Sentencia C-742 (2012, septiembre 26). Demanda de inconstitucionalidad. M. P. María Victoria Calle Correa. Corte Constitucional.

Sentencia T-652 (1996, noviembre 27). Sala de tutelas. M. P. Carlos Gaviria Díaz. Corte Constitucional.

Sentencia T-162 (1998, abril 30). Sala de tutelas. M. P. Eduardo Cifuentes Muñoz. Corte Constitucional.

Sentencia T-512 (1999, julio 15). Sala de tutelas. M. P. Antonio Barrera Carbonell. Corte Constitucional.

Sentencia T-537 (2002, julio 15). Sala de tutelas. M. P. Jaime Córdoba Triviño. Corte Constitucional.

Velásquez, F. (2014). Manual de Derecho penal, Parte general (6a ed.). Bogotá: Ediciones Jurídicas Andrés Morales.

Velásquez, F. (2009). Derecho Penal, Parte General, t. I. Santiago de Chile: Editorial Jurídica de Chile.

Velásquez, F. (2009). Derecho Penal, Parte General, t. II. Santiago de Chile: Editorial Jurídica de Chile.

Velásquez, F. (2013). Seguridad ciudadana e inseguridad jurídica. En: Revista Digital de la Maestría en Ciencias Penales, (5), 290-318.

Wacquant, L. (2000) Las cárceles de la miseria (trad. de Horacio Pons), Buenos Aires: Manantial.

Zaffaroni, E. R. (1987). Tratado de Derecho Penal, tomo III. Buenos Aires: Ediar. 